\title{
Subordinated Debt Under Bail-in Threat
}

\author{
EDOARDO MARTINO ${ }^{\dagger}$
}

TABLE OF CONTENTS: 1. Introduction; 2. Bail-In, Debt and Creditor's Treatment; 2.1. Raising Capital in the Banking Industry; 2.2. B.R.R.D. and Creditor's Treatment; 3. The Italian Anecdotal Evidence; 3.1. The Narrative and Some Caveat; 3.2. The Market for Subordinated Debt in the Italian Banking System; 4. Empirical Assessment of the Determinants of Subordinated Debt; 4.1. Sample and Variables; 4.2. How to Understand Decision on Subordinated Debt Issuance?; 4.3. Are There Reliable Determinants?; 4.4. Policy Consequences; 5. Convertible Subordinated Bond: A Solution Though Contracts?; 5.1. Contractual Clause for Writing Down and Conversion: a Solving Problem Tool; 5.2. Incentive Structure of Relevant Actors; 6. Conclusions; 7. Appendix.

AвSTRACT: This paper aims to address the role of subordinated liabilities within the new resolution framework resulting from the post-crisis reforms.

In particular, this study starts from the resolution intervention of four Italian banks in November 2015. The legal analysis of that resolution is complemented by an empirical analysis of the determinants of subordinated debt issuances for Italian banks.

From this set of evidence is possible to infer the desirability of a well-functioning and dynamic market for subordinated debt. On the other hand, what clearly emerges is the incompatibility between such a market and the new regulatory framework as it is.

Therefore, the paper, given the compelling arguments showing the inefficiency of a pure mandatory bail-in mechanism for subordinated debt, proposes to complement it with a contractual clause to bail-in subordinated creditors, tailored on coco bonds model, in order to enhance certainty amongst the contractual parties.

KEYWORDS: Law and Economics; Law and Finance; European Banking Union; Banking Resolution; Subordinated Bonds 


\section{INTRODUCTION}

After the global financial crisis in 2007 and the sovereign debt crisis in 2011, the lack of a common regulatory framework for banking supervision and resolution has been identified as one of the main drivers of European, and especially the Eurozone, stagnation.

The European policy maker reacted implementing the European Banking Union (hereinafter E.B.U.) ${ }^{1}$ to enhance financial stability and make a step forward towards a genuine economic and monetary union. ${ }^{2}$ The new E.B.U. consists of three main pillars: ${ }^{3}$ a Single Supervisory Mechanism for the Eurozone (hereinafter S.S.M.), ${ }^{4}$ a new Deposit Guarantee Scheme (hereinafter D.G.S.) ${ }^{5}$ and a new framework for the resolution of distressed banks. ${ }^{6}$

Within the resolution intervention, the bail-in tool attracted the utmost attention of both media and scholars.7 A bank bail-in ${ }^{8}$ is a tool that the Resolution Authority can employ once a resolution is triggered. The power to write down (Article 63 (1)(e) B.R.R.D.) or convert into ordinary shares (Article 63 (1)(f) B.R.R.D.) eligible liabilities issued by the bank under resolution constitute a bail-in. Therefore, a bail-in represents a balance sheet operation

\footnotetext{
${ }^{\dagger}$ Edoardo Martino LL.M., Ph.D. Candidate in Law \& Economics at Rotterdam Institute of Law and Economics, Erasmus School of Law. The author is grateful to Dr. Jaroslaw Beldowski and Dr. Wiktor Wojciechowski for their supervision on this work. Usual disclaimers apply.

${ }^{1}$ See the 'Conclusions document' of the European Council (28/29 June 2012).

${ }^{2}$ See Herman Van Rompuy, Towards A GENUINe ECONOMic AND MONETARY UNiON (2012).

${ }^{3}$ See DANNY BuSH \& GUIDO FERRARINI, EUROPEAN BANKING UNION (2015).

4 Council Regulation 1024/2013 of 15 October 2013 conferring specific tasks on the European Central Bank concerning policies relating to the prudential supervision of credit institutions, 2013 O.J. (L 287), 63.

${ }^{5}$ Directive 2014/49 of the European Parliament and of the Council of 16 April 2014, on deposit guarantee schemes, 2014 O.J. (L 173), 149.

${ }^{6}$ Directive 2014/59, of the European Parliament and of the Council of 15 May 2014 Establishing a Framework for the Recovery and Resolution of Credit Institutions and Investment Firms and Amending Council Directive 82/891/EEC, and Directives 2001/24/EC, 2002/47/EC, 2004/25/EC, 2005/56/EC, 2007/36/EC, 2011/35/EU, 2012/30/EU and 2013/36/EU, and Regulations (EU) No 1093/2010 and (EU) No 648/2012, of the European Parliament and of the Council, 2014 O.J. (L173), 190, and - specifically for the Eurozone - Single Resolution Mechanism - Regulation 806/2014, of the European Parliament and of the Council of 15 July 2014 establishing uniform rules and a uniform procedure for the resolution of credit institutions and certain investment firms in the framework of a Single Resolution Mechanism and a Single Resolution Fund and amending Regulation (EU) No 1093/2010, 2014 O.J. (L 225), 1.

${ }^{7}$ For a survey about the challenges stemming from bail-in, see Goodhart, Charles; Charles Goodhart \& Emilios Avgouleas, A Critical Evaluation Of Bail-Ins As Bank Recapitalisation Mechanisms, SSRN, https://papers.ssrn.com/sol3/papers.cfm?abstract_id=2478647 (Aug. 12, 2014).

${ }^{8}$ See Paul Calello \& Wilson Ervin, From bail-out to bail-in, THE ECONOMIST, Jan. 28, 2010.
} 
to recapitalize and restore the viability of the distressed institution. ${ }^{9}$ In this way, the State should not be "forced" to bail those banks out and, consequently, would avoid burdening tax-payers with bank savings. ${ }^{10}$

The specific objective of this paper is to address the consequences that the new resolution tools have on subordinated liabilities market in a dynamic perspective; meaning that the paper considers not only how the new regulation affects a particular class of creditors, but also whether such new framework incentivizes a shift in the characteristic of subordinated bonds and bondholders and the expected outcome of the whole process.

This paper discusses the desirability of a developed market for subordinated bonds and - at the same time - the inefficiency of a purely mandatory debt conversion regime. Eventually, a contractual model tailored on the contingent capital instrument is proposed to make all the actors involved better-off.

The structure of the paper is as follows: Section $\S 2$ provides an introduction to the banks' financial structure and creditors' safeguards in case of bail-in, as disciplined in the Bank Recovery and Resolution Directive (hereinafter B.R.R.D). Section $\S 3$ analyzes an anecdotal evidence from Italy, where the Bank of Italy, along with Ministry of Economic and Finance, resolved four banks in November 2015. The key point of that resolution intervention was, indeed, writing down the bank subordinated debt. Section $\S$ 4 tries to test empirically which are the determinants of subordinated debt, using a sample of Italian banks and listed subordinated bonds. Finally, Section $\S 5$ discusses the incentives for banks and bondholders to include in their agreement a clause to convert and/or write-down the credit when a given trigger event occurs (Section $§ 5$ ).

Throughout this paper the so-called "Law and Economics" methodology is widely applied. This basically means that the legal analysis concerning bail-in and subordinated bond is closely tied to the analysis of

9 See Simon Gleeson, Special Paper, Legal Aspects Of Bank Bail-Ins, 2012 LoNDon Sch. Econ. FinAN. MKT. GROUP PAPER SERIES II SP205.

${ }^{10}$ During the $2007-08$, crisis almost $37 \%$ of aggregate E.U. Member State GDP was spent to avoid banks failure. See E.C.B. Report on EU Banking Structures, (Sept. 2010), https://www.ecb.europa.eu/pub/pdf/other/eubankingstructures201009en.pdf?cd7ac9e5cf703dabf8 6f 35 ac014 of 225 . 
economic consequences of the legal framework, ${ }^{11}$ borrowing from basic microeconomic theory and econometrics.

\section{BAIL-IN, DEBT AND CREDITOR'S TREATMENT}

\subsection{RAISING CAPITAL IN THE BANKING INDUSTRY}

Before starting any analysis of banks bail-in and its impact on subordinated debt, it seems to be wise taking a step back and examining how banks raise their capital, i.e.: how they make decisions concerning the source for funding firm's activities. In fact, the decisions about capital and debt structure are going to be a crucial aspect of the paper.

An intuitive division is usually drawn between debt and equity, anyhow - given the large variety of debt and equity instrument available - the source of funding can be better visualized as a vector ordered according to the loss absorbency capacity of each particular financial instrument: clearly, pure equity instruments have a higher loss absorbency capacity in case of failure and debt tools have lower and lower capacity to absorb losses. From the investor's standpoint, a greater loss absorbing capacity means a higher risk profile of the investment.

For standard economic reasoning, in deciding its capital structure, each firm strives to find a mix of different capital instruments which maximize the difference between marginal cost and marginal benefit of capital (e.g.: tax incentives, cash flow incentives). ${ }^{12}$

The first issue that has to be highlighted is that a bank's financial structure has many peculiarities compared to non-financial corporations. These can be explained by focusing on two aspects: the role of financial structure for banking activity and the social cost of banks failure. Indeed, the financial structure of banks is per se highly leveraged, as the core business of

\footnotetext{
${ }^{11}$ For an extensive introduction see RoBERT D. COOPER, LAW AND ECONOMICs (Pearson Education eds., 6th ed. 2011). ; see also Louis Kaplow \& Steven Shavell, Economic Analysis Of Law, in 3 HANDBOOK OF Public ECONOMICs 1661-1784 (Martin Feldstein \& A.J. Auerbach eds., 2002).

${ }^{12}$ See Jianping Zhou et al., From Bail-out to Bail-in: Mandatory Debt Restructuring of Systemic Financial Institutions, 12/03 INT'L MONETARY Found STAFF Discussion NoTES, Apr. 24, 2012, at 21.
} 
commercial banks is to transform short term lending (mostly deposits) into long term borrowings. In other words, capital structure is part of what banks do and not only the result of a strategy to raise funds. ${ }^{13}$ Moreover, since bank activities have a systemic importance for economic stability, ${ }^{14}$ the social cost of banks bankruptcy is by far more severe than for every other kind of corporation. ${ }^{15}$

Any policy suggestion has to carefully consider those two aspects in making proposals to reform banks capital structure whose purpose is to enhance the loss absorbency capacity of banks' liabilities.

After the global financial crisis, (too) high leverage in banks' balance sheets was intensively criticized, and several scholars proposed to set a minimum requirement of equity far higher than the Basel III requirements. The underlying assumption of most of those proposals is the belief that gathering debt is not cheaper than raising equity. ${ }^{16}$ This position borrows from Modigliani and Miller's Indifference Propositions, according to which assuming "no cost of bankruptcy" and "perfect information" - the cost of raising capital is independent of the debt/equity structure of the firm. ${ }^{17}$ The departure from that proposition generates a huge stream of literature on corporate finance which will be helpful later on, in the empirical analysis of determinants of subordinated debt issues. In fact, the "no cost of bankruptcy" and the "perfect information" assumptions, which represent the baseline of the Modigliani and Miller's model, turn to be rather unrealistic, especially for the banking sector.

Furthermore, increasing the share of equity in banks financial structure cannot be considered a policy goal per se. In fact, the first-order purpose is to enhance loss absorbency capacity of bank liabilities and, hence, make them more resilient. Thus, in governing future financial crisis, the debt shall play a

${ }^{13}$ See Paul Davies, The Fall And Rise Of Debt: Bank Capital Regulation After The Crisis, 16 Eur. Bus. ORG. L. REV., 491, 500 (2015).

${ }^{14}$ See Olivier Blanchard, Giovanni Dell'Arriccia \& Paolo Mauro, Rethinking Macroeconomic Policy, 42 J.MONEY, CREDIT AND BANKING 199, 206 (2010).

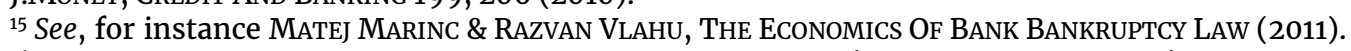

${ }^{16}$ See, e.g., Anat admati \& Martin Hellwig, The Bankers' NeW Clothes: What's Wrong With BANKING AND WHAT To Do ABout IT (updated ed., 2014).

${ }^{17}$ See Franco Modigliani \& Merton Howard Miller, The Cost Of Capital, Corporation Finance And The Theory of Investment, 48 THE AM. ECON. REV. 261-297 (1958). 
role in absorbing losses, and this can be considered the overarching policy goal of the bail-in. ${ }^{18}$

For what specifically concerns subordinated debtholders in banks, their role was highly studied at the beginning of the millennium, during the discussion preceding the Basel II agreement, as a tool to enhance bank's governance via market discipline mechanism. ${ }^{19}$ A certain consensus arose around the fact that imposing market discipline via subordinated debt is technically feasible, even though the market discipline mechanism was disturbed by the implicit guarantee of the sovereign on domestic banks solvency.

Although those represent quite outdated evidence, they acquire a new importance thinking that the new E.B.U. mainly aims to eliminate both the implicit guarantee of domestic sovereignty and the "too big (or too complex, international, important) to fail" policy. Therefore, considering that evidence and the new European institutional framework, a considerable improvement in market discipline mechanism via subordinated debt can be predicted, given the greater incentives to fully internalize the costs (i.e.: risk) of subordinated bonds, ${ }^{20}$ since subordinated bondholders are particularly prone to bear losses in a resolution process.

However, the bail-in tool goes far beyond the mere market discipline mechanism, since it enhances and makes effective the loss absorbency capacity of debt instruments ${ }^{21}$.

On the other hand, the role of subordinated debt in the bail-in process there are not straightforward answers, as well noted by Paul Davies:

Whilst subordinated debt has survived a real-life performance which would have caused most teams to be relegated, its final role in bank capital is not yet absolutely clear. The FSB is the cheer-leader for subordinated debt in resolution [...]. The Bank Recovery and

\footnotetext{
${ }^{18}$ Gleeson, supra note 9, at 267.

19 See Andrea Sironi, Testing for Market discipline in the European Banking industry: evidence from subordinated debt issues, 35 J. Money, CREDIT AND BANKING 443 (2003) ; see also Jürg M. Blum, Subordinated debt, market discipline and banks' risk taking, 26 J. BANKING \& FIN. 1427 (2002).

${ }^{20}$ Zhou et al., supra note 12, at 20.

${ }^{21}$ See Basel Commitee on BAnKing Supervision, Consultative Document Proposal to ensure the loss ABSORBENCY OF REGULATORY CAPITAL AT THE POINT OF NON-VIABILITY (2010) http://www.bis.org/publ/bcbs174.pdf.
} 


\begin{abstract}
Resolution Directive of the E.U. requires the issuance of subordinated debt to promote resolution but is circumspect on the actual proportion. ${ }^{22}$
\end{abstract}

The last remark about the importance of pricing internalization should be devoted to the positive repercussions of reducing the spillover effect from domestic banks to sovereign and vice versa. As incisively noticed by Paul Tucker: "For banking risk, the genie is out of the bottle. If the risk is not priced into bank bonds, it will be priced into government bonds. The people deserve better".23

\title{
2.2 B.R.R.D. AND CREDITOR'S TREATMENT
}

The narrative and the policy goals that led to the B.R.R.D. and bail-in is nowadays well known and a systemic introduction on the theme falls well beyond the scope of this paper. ${ }^{24}$ Nevertheless, a brief introduction to the principles on creditors' treatment included in the B.R.R.D. is useful both to concretize the theoretical statements made in $\S 2.1$ and to introduce the anecdotal evidence in $\S 3$. Three main aspects are to be discussed: which are the bail-in eligible creditors; what are their safeguards during the resolution process and their role in capital regulation.

The idea itself of the bail-in makes clear that the position of creditors vis-à-vis the bank insiders and the resolution authorities represents one of the key elements of the new framework. ${ }^{25}$

To begin understanding the position of creditors under B.R.R.D., a good starting point is the second part of the recital $n$. 67: the goal of creditors involvement within the resolution process is to avoid moral hazard of - at least big - creditors, giving incentives to engage in monitoring activities. This

22 Davies, supra note 13 , at 510.

23 Paul Tucker, The resolution of financial institutions without taxpayer solvency support: Seven retrospective clarifications and elaboration, CTR. FOR ECON. POL'Y RES. EUR. SUMMER SYMP. IN ECON. THEORY, Jul. 3, 2014, at 1, 10.

${ }^{24}$ To have a good idea of what happened both from a policy and legal perspective see, FINANCIAL STABILITY BOARD, KEY ATTRIBUTES OF EFFECTIVE RESOLUTION REGIMES FOR FINANCIAL INSTITUTIONS,. (2014); Goodhart \& Avgouleas, supra note 7; Thomas Conlon \& John Cotter, Anatomy of a bail-in, 15 J. OF Fin. STABILITY 257 (2014); Christos Hadjiemmanuil, Bank Stakeholders' Mandatory Contribution to Resolution Financing: Principle and Ambiguities of Bail-In, 2015 EUR. CENT. BANK LEGAL CONF., 225. ${ }^{25}$ See Jens-Henrich Binder, The Position of Creditors Under the BRRD, BANK OF GREECE CTR. FOR CULTURE (2016). 
rationale holds if and only if creditors are actually capable of monitoring banking activities, i.e.: creditors with sufficient expertise. ${ }^{26}$

Thus, in determining the classes of bail-in eligible liabilities, three guidelines have to be considered: exclude debt holders that threaten the systemic stability in case of write-down or conversion (the so-called runnable liabilities); include debt holders that can successfully fulfill the monitoring task; exempt particular classes of creditors that deserve to be protected for other reasons.

The B.R.R.D. normative strategy consists in granting a general and exante exemption from bail-in to specific groups of creditors (Article 44 (2) B.R.R.D.) and allocate to the Resolution Authority the power to exempt on a case-by-case assessment other liabilities that are theoretically bail-in eligible. The purpose of this case-by-case assessment is to preserve the continuity of critical activities of the resolving bank and avoid the risk of contagion (Article 44 (3) B.R.R.D.).

In particular, a general ex-ante exemption has been granted to depositors whose deposits are covered by the D.G.S. (deposit up to 100,000€); secured liabilities (e.g.: covered bond); liabilities toward client for what concern fiduciary custody of assets; short-term inter-bank operations; wholesale short-term arrangements (e.g.: repos); liabilities toward workers and retail creditors supplying good and services.

Therefore, all the other liabilities fall within the scope of bail-in, i.e.: the resolution authorities have the power to write off or convert them, according to the safeguards of article 34 of the Directive:

1) creditors bear losses after shareholders according to the order of priority of their credits under classical insolvency procedure (Article 34 (1)(b));

2) within each class, creditors are treated in an equitable manner (Article $34(1)(f))$;

${ }^{26}$ Cf On this instance GÖTZ, Martin R., et al. Should the marketing of subordinated debt be restricted/different in one way or the other? What to do in the case of mis-selling? Goethe University Frankfurt, Research Center SAFE-Sustainable Architecture for Finance in Europe, 2016. 
3) creditors cannot bear higher losses than would have been incurred under normal insolvency procedure (no creditor worse-off principle - Article $34(1)(g))$.

The application of the first two principles, apart from some ambiguities ${ }^{27}$ and difficulties in the coordination of likely divergent national legislations, appear quite straightforward. On the other hand, the no-creditor-worse-off principle (hereinafter N.C.W.O.) creates much more doubts and implementation issues. Moreover, it is crucial to analyze this principle in order to understand what will be the likely role of subordinated debt in the new institutional framework of banks resolution.

The N.C.W.O. principle asks the resolution authority to make a counterfactual assessment, establishing (Article 74) the value of bailed-in liabilities that would have resulted from the normal insolvency procedure. This hypothetical value represents the minimum level of protection for creditors; ${ }^{28}$ but, as in all the cases, requires a difficult counterfactual assessment, thus serious effectiveness concerns might arise. ${ }^{29}$

These concerns, which are surely serious and well-grounded, can be approached in a wholly different way, looking at the N.C.W.O. principle as a substitute for the lack of ex-ante safeguards (vote, court hearing, public consultation, etc.) for creditors. ${ }^{30}$ To better grasp the economic rationale of the latter statement, the very first step is to transpose the N.C.W.O. protection into the classic Law and Economic trade-off between "Property Rule" and "Liability Rule". ${ }^{1}$

First of all, the underlying entitlement that N.C.W.O. principle wants to grant shall be defined as follows: "In the B.R.R.D., bailed-in creditors are entitled not to suffer higher losses compared to a liquidation scenario"; therefore, the only relevant point to be answered is: how to enforce such an entitlement? In this instance, the entitlement is not protected through an

\footnotetext{
${ }^{27}$ Hadjiemmanuil, supra note 24, at 225-248, 241-244.

${ }^{28}$ Binder, supra note 25 , at 10.

${ }^{29}$ See George Jacobs \& David Mitchell, The no-creditor-worse-off principle from a valuation perspective: standing in the shoo of a hypothetical liquidator, 29 BUTTERWORTH'S J. INT'L BANKING AND FIN. L. (2014). ${ }^{30}$ Gleeson, supra note 9, at 265.

${ }^{31}$ See Guido Calabresi \& A. Douglas Melamed, Property Rules, Liability Rules and Inalienability: One View of the Cathedral, 85 HARV. L REV. 1089 (1972).
} 
absolute and ex-ante mechanism that prevents creditors to be worse-off, which in Calabresi and Melamed taxonomy is called "property rule". Nevertheless, creditors are still protected through a different mechanism. In fact, the N.C.W.O. principle acts as a blueprint that should guide the resolution authority's activities plus - and especially - as ex-post "liability rule" that assure the compensation of creditors worse-off in the resolution process (as provided by Article 75).

Assuming a costless litigation procedure, the economic outcome stemming from a property and liability rule will be equivalent for the creditors. If the latter assumption is relaxed, the rationale behind such an institutional design can be summarized as follows: bail-in represents a value-creating process compared to the traditional insolvency procedure. In a nutshell, the reduction in transaction costs overweight the positive cost of administrating the Justice.

Considering the time constraints under which a bail-in shall be applied and the value of systemic stability, the approach of European regulator makes a lot of sense from a social welfare standpoint.

Finally, to properly grasp the role of debt - and thus creditors - in the E.B.U. mechanism, a brief overview on financial structure regulation contained in B.R.R.D. has to be presented. ${ }^{32}$ First of all, Article 45 B.R.R.D. provides that institutions shall meet at all times a minimum requirement of bail-in eligible liabilities (hereinafter M.R.E.L.).

Article $45 \S 4$ lists the necessary characteristic to consider a liability as eligible: be issued and entirely paid up; not deriving from infra-group operation; have a remaining maturity of at least one year; not arising from a derivative or a deposit covered by D.G.S.

\footnotetext{
${ }^{32}$ Anyhow, the core of the financial structure regulation is contained C.R.R./C.R.D. IV package represents the European implementation of Basel III accords. ( For a survey of the main regulatory features of C.R.R./C.R.D. IV), see Rainer Masera, CRR/CRD IV: the trees and the forest, SSRN, https://papers.ssrn.com/sol3/papers.cfm?abstract_id=2418215; (On the possible overlaps and inconsistencies between BRRD and CRR/CRD IV regulation) see Bart Joosen, Bail in Mechanisms in the Bank Recovery and Resolution Directive, SSRN, https://papers.ssrn.com/sol3/Papers.cfm?abstract_id=2511886.
} 
In this instance, the approach of E.U. legislator appropriately departs from the one-size-fits-all paradigm. ${ }^{33}$ Indeed, Article 45 (6) B.R.R.D. provides several criteria to the resolution authorities to determine a specific M.R.E.L. for each institution. ${ }^{34}$

Another relevant piece of this complex puzzle is a document about Total Loss Absorbency Capacity (hereinafter T.L.A.C.) for Systematically Important Financial Institutions (hereinafter S.I.F.Is.), issued by Financial Stability Board (2015). F.S.B. suggests setting a minimum fix requirement of bail-in eligible liabilities between sixteen and twenty percent of risk-weighted assets (hereinafter R.W.A. (Pillar 1) plus an adjunctive buffer to be determined on an individual basis (Pillar 2). 35

Nonetheless, for what is here of interest, subordinated liabilities are certainly part of eligible liabilities if the remaining maturity period is longer than one year. At the same time, they can or cannot be part of the regulatory capital (as Additional Tier 1 or Tier 2) depending on whether the tight Capital Requirements Regulations (hereinafter C.R.R.) standards are fulfilled.

The next section is going to apply this theoretical and normative framework to an Italian case study of November 2015, when four mediumsmall banks were resolved by the National Resolution Authority (i.e.: Bank of Italy) and the role of subordinated debt was crucial.

\footnotetext{
33 The one-size-fits-all approach is, instead, adopted by C.R.R./C.R.D. IV package in order to establish a consistent internal market for banks. This approach has been widely criticized since it artificially creates higher compliance costs for medium and small banks, favouring S.I.F.Is. which can enjoy economies of scale.

34 The European Banking Authority implemented a Draft Regulatory Technical Standards to concretely implement such criteria, see EBA FINAL Draft Regulatory Technical Standards on criteria for determining the minimum requirement for own funds and eligible liabilities under Directive 2014/59/EU, EBA/RTS/2015/05, final (3 July 2015); see also EBA Interim report on MREL, Report on implementation and design of the MREL framework, EBA-Op-2016-12, (19 July 2016). The base to determine the bank specific requirement is the "own fund requirement" provided by C.R.R. plus any additional requirement to hold own funds in excess. From this starting point, the Resolution Authority can increase or even decrease the amount of M.R.E.L. considering the risk profile, the business model and the funding model of each institution.

35 The conformance period is not sure yet, but not before 2019. The application of T.L.A.C. standards is consistent with M.R.E.L., even though in other instances, the minimum requirement pursuing B.R.R.D. can substantially deviate from T.L.A.C. standards.
} 


\section{THE ITALIAN ANECDOTAL EVIDENCE}

\subsection{THE NARRATIVE AND SOME CAVEATS}

The 21st November 2015, the Bank of Italy resolved four Italian territorial banks via "Sale of goods" tool to a bridge entity. The day after, the bureaucratic process to establish the bridge banks was speeded up by the government with the so-called "Bank Saving Decree" (D.L. n. 183/2015).

The four resolved banks are Banca Marche, Banca Popolare dell'Etruria e del Lazio, CariChieti and Cassa di Risparmio di Ferrara who together used to hold $1 \%$ of national deposits ${ }^{36}$. Despite the size of these banks being rather small, considering the structure of the Italian entrepreneurial system, their viability of was crucial (see Agostino et al., 2011), since those are "territorial" banks, coming from a history somehow related to cooperative credit. Therefore, the stability and continuity of the credit lines toward S.M.Es. within their geographical area assumed an importance far beyond the actual amount of deposits or the size of their assets.

The Bank of Italy, following the strategies arranged in the Resolution Plans, created four bridge banks and transferred to them all the assets and liabilities, except for equity and subordinated debt. ${ }^{37}$ A procedure for selling the four bridge institutions has already started, and Bank of Italy is striving to conclude it as soon as possible.

On the other hand, for the sake of administrative efficient, only one Asset Management Vehicle,38 which can be labeled as 'Bad Bank', 39 has been created, gathering all the equity and subordinated debt of the resolved banks

\footnotetext{
36 See Lorenzo Stanghellini, The Implementation of the BRRD in Italy and its First Test: Policy Implications, 2 J. FIN. REG. 157, 158 (2016); see also Donato Messineo, Il provvedimento «salvabanche»: il trattamento di azionisti e creditori nella nuova disciplina delle crisi bancarie [The "SalvaBanche" intervention: shareholders and creditors treatment in the new banking crisis framework], 36 QUADERNI COSTITUZIONALI 102 (2016).

37 The Slovenian Supervisory Authority followed the same strategy in 2013. Recently E.C.J. ruled for the legitimacy of bailing-in subordinated liabilities. See Case C-526/14, 19th July 2016.

${ }^{38}$ Directive 2014/59, of the European Parliament and of the Council of 15 May 2014 Establishing a Framework for the Recovery and Resolution of Credit Institutions and Investment Firms and Amending Council Directive 82/891/EEC, and Directives 2001/24/EC, 2002/47/EC, 2004/25/EC, 2005/56/EC, 2007/36/EC, 2011/35/EU, 2012/30/EU and 2013/36/EU, and Regulations (EU) No 1093/2010 and (EU) No 648/2012, of the European Parliament and of the Council, 2014 O.J. (L173) 4, 5 .

39 Stanghellini, supra note 36 , at 159.
} 
on the liabilities side and some non-performing loan on the asset side. $4^{0}$ The National Resolution Fund owes the capital of both good and bad banks..41 From a balance sheet perspective, the situation of the former banks, the new bridge banks, and the bad bank is summarized in Table $1 .{ }^{42}$

Balance Sheet Situation

Data are simply translated from Bank of italy 2015:5 - Data in billion $€$

\begin{tabular}{|c|c|c|c|}
\hline \multicolumn{4}{|c|}{ Bridge Banks - Aggregted Data } \\
\hline Assets & & Liabilities & \\
\hline Loans, Investment, & & De posits, bond and & \\
\hline otherassets Inon- & 24,5 & other fin ancial & 27,8 \\
\hline are not present) & & instruments & \\
\hline Creditsvs. Bad & & Equity lowed by & \\
\hline Bank Iguaranteed & 1,5 & Resolution Fund) & 1,8 \\
\hline by Re solution & & & \\
\hline Cash & 3,6 & & \\
\hline Total & 29,6 & Total & 29,6 \\
\hline
\end{tabular}

\begin{tabular}{|l|l|l|}
\hline \multicolumn{3}{|c|}{ New Banca delle Marche } \\
\hline \multicolumn{2}{|c|}{ Assets } & \multicolumn{1}{|c|}{ Liabilities } \\
\hline $\begin{array}{l}\text { Loans, Investment, } \\
\text { otherassets (non- } \\
\text { perform ing loans } \\
\text { are not present) } \\
\text { Credits v s. Bad } \\
\text { Bank (guaranteed } \\
\text { by Re solution } \\
\text { Cash }\end{array}$ & $\begin{array}{l}\text { Deposits, bond and } \\
\text { 0,9 }\end{array}$ & $\begin{array}{l}\text { E quity (O wed by } \\
\text { other financial } \\
\text { instruments }\end{array}$ \\
Resolution Fund) & 14,3 \\
Total & 2 & 1 \\
\hline
\end{tabular}

\begin{tabular}{|c|c|c|c|}
\hline \multicolumn{4}{|c|}{ New Banca dell'Etruria e del Lazio } \\
\hline Assets & & Liabilities & \\
\hline Loans, Investment, & & Deposits, bond and & \\
\hline $\begin{array}{l}\text { otherassets (non- } \\
\text { pe rforming loans } \\
\text { are not present) }\end{array}$ & 6,1 & $\begin{array}{l}\text { other fin ancial } \\
\text { instrum ents }\end{array}$ & 6,7 \\
\hline Credits vs. Bad & & E quity lo we d by & \\
\hline $\begin{array}{l}\text { Bank Iguaranteed } \\
\text { by Re solution }\end{array}$ & 0,3 & Resolution Fund) & 0,4 \\
\hline Cash & 0,7 & & \\
\hline Total & 7,1 & Total & 7,1 \\
\hline
\end{tabular}

\begin{tabular}{|c|c|c|c|}
\hline \multicolumn{4}{|c|}{ New Cassa di Risparmio di Chieti } \\
\hline Assets & & Liabilities & \\
\hline Loans, Investment, & & De posits, bond and & \\
\hline $\begin{array}{l}\text { othe rassets (non- } \\
\text { pe rform ing loans } \\
\text { are not present) }\end{array}$ & 3,1 & $\begin{array}{l}\text { other fin ancial } \\
\text { instrum ents }\end{array}$ & 27,8 \\
\hline Credits vs. Bad & & E quity lo we d by & \\
\hline $\begin{array}{l}\text { Bank Iguaranteed } \\
\text { by Re solution }\end{array}$ & 1,5 & Resolution Fund) & 1,8 \\
\hline Cash & 3,6 & & \\
\hline Total & 3,4 & Total & 3,4 \\
\hline
\end{tabular}

\begin{tabular}{|c|c|c|c|}
\hline \multicolumn{4}{|c|}{ New Cassa di Risparmio di Ferrara } \\
\hline \multicolumn{2}{|l|}{ Assets } & \multicolumn{2}{|l|}{ Liabilities } \\
\hline Loans, Investment, & & De posits, bond and & \\
\hline otherassets (non- & 2,9 & other fin ancial & 3,5 \\
\hline are not present) & & instruments & \\
\hline Creditsvs. Bad & & of by & \\
\hline Bank Iguaranteed & 0,2 & Equity lowe aby & 0,2 \\
\hline by Re solution & & & \\
\hline Cash & 0,6 & & \\
\hline Total & 3,7 & Total & 3,7 \\
\hline
\end{tabular}

\begin{tabular}{|lr|lr|}
\hline \multicolumn{3}{|c|}{ Bad Bank } \\
\hline \multicolumn{2}{|c|}{ Assets } & \multicolumn{2}{|c|}{ Liabilities } \\
\hline $\begin{array}{l}\text { Non-Performing } \\
\text { Loans }\end{array}$ & 1,5 & $\begin{array}{l}\text { Debt Vs. Bridge } \\
\text { Banks }\end{array}$ & 1,5 \\
Cash & 0,1 & $\begin{array}{l}\text { Equity (O Wed by } \\
\text { Resolution Fund) }\end{array}$ & 0,1 \\
Total & $\mathbf{2 9 , 6}$ & Total & $\mathbf{2 9 , 6}$ \\
\hline
\end{tabular}

Table 1 - Balance-sheet situation for resolved Bank, 22nd November 2015.

${ }^{40}$ Given the systemic relevance of non performing loans in Italian Banking System, currently there are proposals to make that "Bad Bank" the Italian systemic bad bank to cope with future possible resolution interventions.

${ }^{41}$ The Asset Management Vehicle has been established by the National Resolution Fund, which was - in turn - created few days before the resolution intervention, pursuant to Articles 45 and ff. of the D.Lgs. n. 180/2015.

42 BANK OF ITALY, Information about the crisis solution of Banca Marche, Banca Popolare dell'Etruria e del Lazio, CariChieti and Cassa di Risparmio di Ferrara (Informazioni sulla soluzione delle crisi di Banca Marche, Banca Popolare dell'Etruria e del Lazio, CariChieti e Cassa di Risparmio di Ferrara) (2015). 
Therefore, Bank of Italy applied a de facto bail-in, even though the legal instrument currently employed is different since the full-speed bail-in regulation entered into force only on the 1st January 2016. Thus, the relevant institutional framework is the 2013 Banking Communication on "burden sharing". 43

For some obscure reasons very little has been written on this argument by Italian scholars so far. ${ }^{44}$ Hence, this paper also wants to try filling such a gap. First of all, this resolution intervention dealt with the idiosyncratic crisis of relatively small banking institutions, while - in the previous Section -the importance of coping with a systemic crisis of S.I.F.Is. was stressed.

The crisis came from serious mismanagements of all the four resolved banks; indeed, all the four banks were already subjected to severe supervisory intervention by the Bank of Italy. The only "systemic" aspect of the crisis is the crucial role of non-performing loans, which represents one of the central problems of Italian banking system. In fact, during the IV quarter of 2015, the non-performing loans amount was approximately $€ 350$ billion, representing almost the $20 \%$ of total loans. 45

This contingency reflects and fosters many concerns around the actual effectiveness of bail-in as an on-going concern: an excellent tool for mostly idiosyncratic crisis, as substitute of liquidation; but presenting a high risk to be useless or even harmful in case of resolution of big institutions in systemic crisis. $4^{6}$

Currently, there are no counterchecks, but it is reasonable to think that the strategy of resolution authorities shall consist in "playing tough" with small distressed institutions in the next couple of years to engender a credible threat and furnish the right incentives to maintain banks viability. In a

43 Commission Communication on the Application, from 1 August 2013 , of State Aid Rules to Support Measures in Favour of Banks in the Context of the Financial Crisis ( 'Banking Communication' ), 2013 O.J. (C 216) 1.

44 See Antonella Antonucci, Fra Opacità E Regole Tossiche: Il Ruolo Degli Scenari Probabilistici. Scritto per Il Convegno 'Salvataggio Bancario E Tutela Del Risparmio' [Between Opacity And Toxic Rules: The Role Of Probabilistic scenarios. Written For The Conference'Banking Rescue And Saving Protection'], RIV .DIR. BANC., Feb. 2016, at 1.; Stanghellini, supra note 36; Messineo, supra note 44.

45 BANK OF ITALY, Statistical Bulletin - quarter 1. (2016).

${ }^{46}$ See Goodhart \& Avgouleas, supra note 7, at 20; MCANDREWS, James, et al. What Makes Large Bank Failures So Messy and What to Do about It?. Economic Policy Review, Forthcoming, 2014. 
nutshell: the best bail-in for S.I.F.Is. is the bail-in that will never happen because of the credible threat established by the regulatory framework itself.

The resolution intervention has been costless for taxpayers so far since the Resolution Fund provided the liquidity to guarantee the continuity of critical activities, via an advance payment by Unicredit, Banca Intesa SanPaolo e UbiBanca. ${ }^{47}$ Thus, the policy goal of avoiding taxpayers' expenditures for banks resolution seems to be - at least for the moment - achieved.

As anticipated above, subordinated bonds played a crucial role: they have been fully allocated to the bad bank as the offset for the non-performing loans (see again Table 1). The Italian Resolution Authority (Resolution Unit of Bank of Italy) publicly admitted that the operation intentionally took place in the window between the B.R.R.D. transposition within the Italian legal system 48 and the 1st January 2016, when bail-in entered into force. So that, it was possible to avoid both the standard atomistic liquidation and the use of the "full bail-in tool". 49 The concerns about using bail-in arose from the fact that under bail-in regime a substantial amount of non-subordinated debt should have been written off. Thus, the political choice of the Resolution Authority, along with Ministry of Economy and Finance, was to use subordinated debt as a cushion to protect senior creditors.

The transitory regime in part justifies and explains this approach: people that invested in non-subordinated bond before the "burden-sharing" document and the B.R.R.D. drafts were not able to fully internalize the risk of the financial instruments they were buying because of the previous distorted incentives on which they relied. ${ }^{50}$

\footnotetext{
47 See BANK OF ITALY, Information about the crisis solution of Banca Marche, Banca Popolare dell'Etruria e del Lazio, CariChieti and Cassa di Risparmio di Ferrara (Informazioni sulla soluzione delle crisi di Banca Marche, Banca Popolare dell'Etruria e del Lazio, CariChieti e Cassa di Risparmio di Ferrara) (2015).

$4^{8}$ D.Lgs. n. 180/2015 and D.Lgs. n. 181/2015.

49 See BARBAGALlO, Carmelo. Camera dei deputati - Indagine conoscitiva sul sistema bancario italiano. Audizione di Carmelo Barbagallo. Capo del Dipartimento Vigilanza Bancaria e Finanziaria Banca d'Italia [Italian Chamber of Deputies - Cognitive survey over Italian banking system. Hearing of Carmelo Barbagallo. Chief of Banking and Financial Supervisory Department, Bank of Italy] (Dec. 9, 2015), p. 9.

${ }^{50}$ It is important to note that "Trust" is an informal institution that has a great importance in social behaviors and, at the same time, is particularly troublesome and time-consuming to generate in the society. See e.g., PINOTTI, Paolo. Trust and regulation: addressing a cultural bias. Bank of Italy Temi di Discussione (Working Paper) No, 2009, 721.
} 
Nonetheless, those arguments can be generalized, at least up to a certain extent. In fact, there is a misalignment between bail-in eligible liabilities and the loss absorbency capacity of each of them, as designed by C.R.R./C.R.D. IV package. Thus, for resolution authorities writing down senior creditors claims will never be an easy call ${ }^{11}$ and it is plausible that resolution policy will opt for permanently using subordinated debt as a cushion even when the resolution mechanism will work at full speed.

Despite the protection of senior creditors, the resolution has been greatly criticized. The widely perceived unfairness was mainly due to severe mismanagement in the allocation of those financial instruments. For example, resolved banks commonly asked their clients to subscribe subordinated bonds to open or keep credit lines for SMEs, ${ }^{52}$ as an informal collateral, without giving proper information about their risk profile, breaching de facto the standards established by Markets in Financial Instruments Directives (hereinafter MiFID). ${ }^{53}$

As current final episode of this narrative, the Italian government provided for a reimbursement procedure for a portion of written-off debt holders. ${ }^{54}$ The overall result of this refund operation consists of shifting a part of the resolution burden from bank insiders to the banking system as a whole, via the National Resolution Fund, realizing a sort of "private bail-out" intervention. This aspect, together with the use of subordinated debt to protect senior creditors, can give an idea of the future resolution policies.

As was expected, the conclusion of the story after the completion of the sale of the bridge institutions, will be that the new, viable, banks will not be strictu sensu "territorial" anymore. In fact, three out of four banks have been acquired by UBI Banca, while - at the time I am writing - there are still

\footnotetext{
${ }^{51}$ See Binder, supra note 25.

${ }^{52}$ On the risk of allocating debt to bank's clients, even for the overall stability of the institution, see Stanghellini, supra note 36, at 161.

53 See for an extensive introduction about MiFID, JeAn-PIERre CASEy \& Karel LANNoo, The MiFID REVOLUTION (2009). For what specifically concerns MiFID and subordinated debt, see Gotz et al., supra note 26.

54 According to the procedure depicted in the D.L. n. 59/2016 - "Urgent measures for liquidating banks investors".
} 
ongoing negotiation with BPER for the last good banks still managed by the Bank of Italy. .55

It is important to notice how the acquirers of the good banks are going to pay just a symbolic price for the acquisition. The main issues on which the parties have been contracting about are the management of non performing loans (hereinafter N.P.L.) and the level of additional Common Tier Equity 1 (hereainafter CET1) to be raised in order to be able to sustain those acquisitions.

This conclusion could cause some problems to the S.M.Es. network and their funding costs; moreover, the lack of trust resulting from this story will not be easy to fix. Nonetheless, even if counterfactual assessments are always difficult to make and prove, the intuition is that the situation could have been far worst without this resolution intervention since the atomistic liquidation of the resolved banks would have threatened the continuity of the territorial S.M.Es. themselves.

\subsection{THE MARKET FOR SUBORDINATED DEBT IN THE ITALIAN BANKING SYSTEM}

To link the narrative of the resolution intervention of $\S 3.1$ and the empirical analysis of $\S 4$ is crucial to understand the scope and the functioning of the Italian market for banks subordinated bonds. Some figures about the market itself can give a quite accurate idea of what we are dealing with.

The 31st October 2015, the issued subordinated bond amounted to $€ 67,2$ billion of which $€ 8.5$ billion, i.e.: about $13 \%$ of the entire amount of issued bonds, were held by the issuing banks themselves. Thus, there were $€ 58,7$ billion of bonds floating in the market, of which over the $50 \%$ allocated to individual investors and households (thirty-one billion). ${ }^{56}$

Again, some figures might facilitate the understanding of what $€ 67$ billion mean in the Italian banking system: the total assets of the seventh

\footnotetext{
${ }^{55}$ Insofar, there are no ufficial documents nor discosure of contractual terms, but only an official press release from the Bank of Italy, (2015)

https://www.bancaditalia.it/media/comunicati/documenti/2017-01/cs_good_bank.pdf.

56 See BANK OF ITALY, Informazione sui detentori di obbligazioni subordinate [Information about subordinated bond holder]. Unfortunately there are no data available on the share who are also client of the issuing bank.
} 
Italian banking group (Banco Popolare dell'Emilia Romagna) amount to €61 billion and the total regulatory capital of the first Italian banking group (Unicredit) amounts to $€ 55$ billion.

Moreover, investing in banks' subordinated bonds seems to be very popular when looking at household investment preferences. In fact, in 2015 the volume of Italian household financial investments is $€ 3,848$ billion of which 727 are bank deposits, and only 60 billion are listed stocks, ${ }^{57}$ while 30 are in banks subordinated debt (i.e.: almost $1 \%$ of total investments).

A possible explanation of those figures could be that Italian households are highly risk-adverse and under the previous regime, where the State indirectly subsidized banks bonds through the implicit guarantee of bail-outs, this type of investment attracted them since the risk profile was close to zero and the interest rate was about $1.5 \%$ higher than that of senior bonds. ${ }^{58}$

After the new regulatory stream, some variations were predictable; nevertheless, the events of November 2015 triggered what seems to be an enormous revolution. Indeed, those resolution interventions made clear to everybody, and in particular to small and medium banks under the direct supervision of Bank of Italy, that the new European rules - despite all the effectiveness and efficiency concerns - would have been to be actually applied.

First of all, it is necessary to distinguish between the biggest banks in the system and all the others. In fact, for Intesa San Paolo and Unicredit, which are the only two Italian S.I.F.Is., the market for subordinated bonds is going to disappear because of the lack of supply. Intesa has not issued retail subordinated bond in the last four years, while Unicredit launched a huge buyback campaign for floating subordinated debt from the beginning of 2016.59

Those are the only two Italian commercial banks that can afford to shut down that market, thanks to multiple funding sources and greater stability. For

${ }^{57}$ Accord, Banca d'Italia, Gli investimenti delle famiglie italiane: solo l'1,5\% è destinato alle azioni quotate [Investments of Italians families: just 1,5\% addressed to the Stock Exchange], IL SOLE 24 ORE, March 27, 2015 , at 3.

${ }^{58}$ A partial empiric confirmation of this substitability effect can be found in Regression Table 1 (Appendix), where "Bond Spead" depict a sort of beauty contest between Subordinted Debt issued by banks and 10y Italian Governamental Bond.

59 Unicredit offered to buy back up to 1.8 billion of subordinated bonds. According to the last information available the share of adhesion was over $60 \%$. Compare http://www.ft.com/cms/s/0/f5d8fb6a-c04b-11e5-9fdb-87b8d15baec2.html. 
all the other banks the stream of financial reforms affects the demand side and the pricing mechanism.

\begin{tabular}{|c|c|c|}
\hline \multicolumn{3}{|c|}{ Holders of banks subordinated de bt (Data in billion E) } \\
\hline Holder: & Amount & Srare \\
\hline - & $\mathbf{3}$ & 5,115 \\
\hline 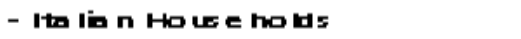 & $3 \mathbf{1}$ & 52,315 \\
\hline - Ito n Ine titurtione orwhich & $\mathbf{3}, 1$ & $13,30 \%$ \\
\hline othe r rina ncis I inte rmed is ries & $3, \mathbf{1}$ & $5,28 \%$ \\
\hline investme ntrunds & $z, z$ & $\exists, 79 \%$ \\
\hline companies & $z, z$ & $3,79 \%$ \\
\hline - Fore is investor & 13,2 & $2 \geq, 495$ \\
\hline - Notcbss iried & 3,4 & 5,795 \\
\hline Tato I & $5 \Xi, 7$ & $100,00 \%$ \\
\hline
\end{tabular}

Table 2 - Banks Subordinated Debt Market in Italy. Bank of Italy, 2015b

On one hand, the demand side of the market for subordinated debt, even if it is an ongoing process and no specific data are now available, a simple and straightforward prediction can be stated: the increased risk profile will cause a shift from households and non-professional investors to professional and institutional investors.

On the other hand, a more accurate description - even though not systematic - of the price for subordinated bonds is feasible since that type of data is more steadily available. Before 22nd November 2015 the average gross yield of a basket composed by eighty-nine subordinated bond was $4.68 \%$. At the beginning of January 2016, the average gross yield of the same bundle of bonds skyrocketed to $6.18 \%$. Moreover, sixteen out of eighty-nine bonds yielded more than $10 \%$, of which seven even more than $20 \% .{ }^{60}$ The most expensive bonds were issued by banks perceived as particularly vulnerable by the market (e.g.: Monte Dei Paschi di Siena and Banca Popolare di Vicenza), which is consistent with the lack of implicit State guarantee.

Those data appear quite astonishing, but they are - at least in part - to the shock provoked by the resolution intervention of the last November. Thus, to precisely evaluate the actual spread between the yields before and after the

\footnotetext{
${ }^{60}$ Data from SkipperInformatica. With Nicola Borzi, Bond subordinati nella bufera: $i$ rendimenti si impennano [Bond subordinated in the storm/blizzard: the profits nose up], IL SOLE 24 ORE, January 20, 2016Il Sole 24 Ore, (Jan. 20, 2016).
} 
bail-in regulation, more time is going to be necessary, even though the tendency is clear and indicates a remarkable increase in subordinated bond prices in the long run either.

\section{EMPIRICAL ASSESSMENT OF THE DETERMINANTS OF SUBORDINATED DEBT}

In the previous Section, the resolution intervention and its first spillover effects were discussed both from the banks, investors and regulatory standpoint; the next step consists in empirically investigating whether the decision of issuing subordinated bonds has some structural determinants. Therefore, the question that this paragraph aims to answer is whether there are reliable determinants that lead a bank to issue subordinated bonds.

This is quite an uncommon step for a legal paper, ${ }^{61}$ nonetheless what follows is going to make clear, at least I hope, how an empirical investigation of legal issues can be useful to - in this very case - evaluate the possibility of implementing more tailored resolution interventions on subordinated bonds in the future.

As far as I am aware, there are no specific studies dedicated to the determinants of subordinated bonds in the banking industry, neither for general corporate subordinated bonds. Nonetheless, the corporate finance literature $^{62}$ about determinants of capital and debt structure for non-financial firms is impressively extensive and represents the unavoidable starting point of this analysis. ${ }^{63}$ In fact, that literature stems from the departure of Modigliani and Miller irrelevance proposition, as analyzed under Section $§$ 2.1.

\footnotetext{
${ }^{61}$ Even though "Empirical legal studies" is for sure an expanding and successful field of research. For a sound introduction on this research methodology see ROBERTO M. LAWLESS, JENNIFER K. RoBbENNOLT \& THOMAS UlEN, EMPIRICAL METHODS IN LAW (2010).

${ }^{62}$ That stream of literature dealing with funding and capital structure decisions of both financial and non-financial corporations. For a survey and introduction, even though not updated, see e.g., Raghuram G. Rajan \& Luigi Zingales, What do we know about capital structure? Some evidence from international data, 50 THE J. Fin. 1421 (1995).

${ }^{63}$ In addition, the empirical corporate finance literature generated over time a certain degree of consensus about some standard variables related to the capital structure of non-financial firms. See e.g., Sheridan Titman \& Roberto Wessels, The Determinants of Capital Structure Choice. 43 THE J. FIN. 1 (1988).; Milton Harris \&Artur Raviv, The Theory of Capital Structure, 46 THE J. FIN. 297 (1991); Id.; and Murray Z. Frank Vidhan K. Goyal, Capital structure decisions: which factors are reliably important?, 38 FIN. MGMT. 1 (2009).
} 
This represents quite an uncommon approach, since the standard one for banking capital structure is based on capital requirement regulations as the only significant departure from Modigliani and Miller proposition, ${ }^{64}$ paying no attention to capital and debt structure of financial firms. Anyhow, stemming from corporate finance literature, there are recent studies focused on banks' capital structure that deviate from the classical approach. Heider and Gropp ${ }^{65}$ focused on bank's leverage, showing a high grade of similarity between their empirical evidence and other studies carried out on non-financial firms. Thus, they concluded that capital requirements are not a first order determinant for a bank's capital structure. For what more closely concerns debt structure, Santos ${ }^{66}$ showed a cost advantage for larger banks in raising debt which is only partially due to the "too big to fail" policy.

Speaking specifically about subordinated debt, the most useful and enlightening study has been carried out by Zanghini, ${ }^{67}$ both for the contents and methodology. He analysed the bank bonds spread, focusing on the role of implicit and explicit public guarantees through the analysis of "Asset swap spread" of different bonds. Moreover, Pop ${ }^{68}$ empirically proved the intuitive idea according to which subordinated creditors are more sensitive than seniors to the risk profile of the issuing institution.

Applying all this theoretical and empirical insights to the present case study, the rest of $\S 4$ tries to establish reliable determinants for Italian subordinated debt issuances in the banking industry.

\subsection{SAMPLE AND VARIABLES}

The analyzed sample consists of twenty-five Italian parent banks that have available balance sheet data on subordinated debt in BankScope Bureau Van

\footnotetext{
64 See FREDERIC MishKin \& AdDISON WeSLey, THE ECONOMICS OF MONEY, BANKING AND FINANCIAL MARKETS (6th ed., 2000).

65 GROPP, Reint; HEIDER, Florian. The determinants of bank capital structure. ECB Working Paper Series n. 1096/2009.

${ }^{66}$ SANTOS, João AC. Evidence from the Bond Market on Banks "Too-Big-To-Fail" Subsidy. Economic Policy Review, Forthcoming, 2014.

${ }^{67}$ ZAGHINI, Andrea. Bank bonds: size, systemic relevance and the sovereign. Working Paper n- 966. Bank of Italy.

${ }^{68}$ POP, Adrian. Market discipline in international banking regulation: keeping the playing field level. Journal of Financial Stability, 2006, 2.3: 286-310.
} 
Dijk DataBase. In building the panel database, the considered time series goes from 2006 to 2015.

Starting from balance sheet data of those banks, the analysis focuses on the listed subordinated bonds issued both in Eurobond and Italian Market, according to the information available in Pillar 3 documents about issued bonds of each bank of the sample. The specific financial data for each of those bonds has been analyzed through Thomson Reuters DataBase.

The final database is made up of 102 bonds issued by thirteen banks. The small number of analyzed banks is due to the fact that most of the small Italian banks issued only retail and non-listed subordinated bonds whose data are not available. Nevertheless, the sample turns out to be quite representative for big and medium Italian banks. Furthermore, some of the results, after a case by case analysis based on economic theory and common sense, can be generalized even for small banks.

Because of the different dates of issue of the analyzed bond, the sample results are unbalanced throughout the time series. Moreover, data on secondary market yields of the bonds were not or only partially available along the time series ( 427 yield observation out of 626 total ones).

(See Table in the next page) 


\begin{tabular}{|c|c|c|c|c|c|c|}
\hline & Variable & Oservations & Mean & Std. Dev. & Min & Max \\
\hline \multirow{4}{*}{ 总 } & Duration & 571 & 9,36 & 2,33 & 5 & 20 \\
\hline & Volume & 626 & 387215 & 412,61 & 5 & 2000 \\
\hline & Yield & 427 & 6,42 & 5,42 & $-1,58$ & 64,43 \\
\hline & Coupon & 626 & 5,40 & 1,65 & 0,87 & 9.5 \\
\hline \multirow{10}{*}{ 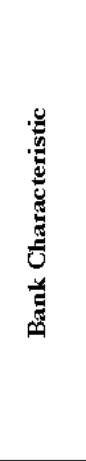 } & Bond spread & 427 & 2,52 & 5,08 & -5.91 & 59,90 \\
\hline & Subordinated debt & 621 & 9855,28 & 7493,11 & 299,00 & 29278,20 \\
\hline & SubDebt/regC apital & 621 & 24,04 & 6,00 & 8,85 & 51,51 \\
\hline & SubDebt/TotLiabilities & 621 & 2,35 & 0,61 & .8267274 & 4,01 \\
\hline & Total Assets & 626 & 453447,10 & 357895,10 & 10765,90 & 1045612 \\
\hline & Net Income & 626 & $-600,38$ & 4155,97 & $-13583,20$ & 7356,00 \\
\hline & ROAA & 626 & $-0,19$ & 0,88 & $-3,92$ & 1,28 \\
\hline & ROAE & 626 & $-4,00$ & 16,22 & $-88,01$ & 16,86 \\
\hline & NPLratio & 623 & 26,10 & 15,73 & 5,67 & 97,12 \\
\hline & Loans/assets & 626 & 60,85 & 7,95 & 49.84 & 82,23 \\
\hline \multirow{2}{*}{ 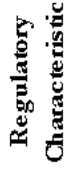 } & Tierl_ratio & 623 & 10,00 & 2,24 & 5.13 & 14,67 \\
\hline & Capital ratio & 623 & 13,07 & 2,18 & 8,00 & 19,77 \\
\hline
\end{tabular}

Table 3 - Summary Statistics

Finally, the data on duration are biased by the fact that some of the subordinated bonds are perpetual, thus in the summary statistics of Table 3 are shown only the bonds with a defined time duration. ${ }^{69}$

From a methodological point of view, in analyzing the data, the linear regression ${ }^{70}$ method is employed. That basically means to check whether the (increasing or decreasing) trend of the dependent variable is somehow correlated with the trend of one or some independent variables, thus establishing correlation linkages. In $\S 4.3$ those correlation linkages are to be discussed in order to draw some policy conclusions. In discussing them a cornerstone is the level of statistical significance of those linkages, meaning the level of certainty that the actual level of correlation is different from zero. As a rule of thumb, a $95 \%$ confidence is considered a good threshold to draw reliable inferences.

\footnotetext{
${ }^{69}$ For a deeper description of the variables used in the study see the Appendix.

${ }^{70}$ All the regressions are run with the Random Effect estimation method, to catch both the crosssectional and time variances. Random Effect has been preferred over Fixed Effect after running the Hausmann-test. Robust Error estimation has been used as well to avoid heteroskedasticity problems.
} 


\subsection{HOW TO UNDERSTAND DECISIONS ON SUBORDINATED DEBT ISSUANCE?}

Using the data set defined above, this study aims to understand what are the drivers of decisions about subordinated debt both from the bank and the investor point of view. In order to do that, the data described in the previous sub-paragraph are used to approximate different aspects concerning the decision of both the issuer and the investor.

For the sake of simplicity, what follows is a mere qualitative description of this process, which explains the variable approximating those decisions (dependent variable) and the variables analyzed to explain such decisions (independent variables). Then, in the footnotes and in the Appendix, the economic and econometric underlying rationale of the models used in the analysis are discussed in more detailed. Throughout the study, the bank's decision of issuing subordinated debt has been disentangled and analyzed under two related but still different perspectives: the decision concerning the overall financial structure of the firm and the decision specifically concerning the structure of regulatory capital.

Firstly, to understand the determinants of these decisions, the data analyzed are related to financial data of the bank (e.g.: balance sheet structure; N.P.L. patio etc.); financial data of the specific bond (e.g.: yield) and some approximation of the bank-specific role of the regulator. ${ }^{71}$ Secondly, the variation on subordinated debt issuances over the last decade is taken into consideration. This is important to understand if economic or legal shocks (i.e.: financial crisis and reform implementation) played a decisive role in the subordinated debt market. Practically, the same variables are to be explained; but now only the evolution over time is computed in order to explain the variations. Finally, the issue at stake is further disentangled taking into account the investors' decisions, which are approximated through the yield on the secondary market and the spread between those yields and the yield of ten-year Italian governmental bonds. This proxy makes sense since the average duration of the analyzed bonds is over nine years, thus investing in banks subordinated debt can be considered a close substitute of investing in

${ }^{71}$ For more detailed on the variables used see Appendix, Variable List Table, where a detailed description of the variables is provided. 
Italian Treasury bond, and so it represents the perfect benchmark for the present study.

\subsection{ARE THERE RELIABLE DETERMINANTS?}

Regression Tables 1, 2 and 3 in the Appendix summarize the empirical findings of the models depicted in the previous paragraph.

The first interesting insight concerns the sharply different outcome in the decisions about financial and regulatory capital structure, indicating that each bank has to face two distinct orders of decisions, following separate aspects.

For what concerns financial structure decisions the 'Capital ratio' and 'Tier1 ratio' parameters sign and magnitude are consistent with common sense: the higher the capital ratio, the higher the subordinated debt ratio; the higher the Tier1 ratio, the lower the subordinated debt structure.

The highly statistical significance of the negative parameter of the dummy "E.C.B. supervision" shows that the less systemic a bank is, the higher the share of subordinated debt. In fact, the S.S.M. entered into force only in 2015. Thus, that variable only indicates the relevance of the requirements to be subjected to direct E.C.B. supervision, which are - indeed - about the systemic importance of the banking institution within European and domestic banking system.

The significant negative parameter of N.P.L. ratio is of particular importance since it is becoming the major issue for the problematic Italian (and even European) banking system. The relatively high-risk profile of the subordinated bonds can explain this evidence: for a bank with a high N.P.L. ratio funding itself by subordinated debt represents a too expensive option.

On the other hand, in deciding the structure of regulatory capital, the banks are remarkably influenced by the spread between the yield of subordinated bonds and the ten-year Italian governmental bond: the higher the spread, the larger the share of subordinated capital. This can be explained 
by the particular attractiveness of investing in bank's subordinated bonds, for the reasons discussed in $\S 3.2$.

Another important result, confirming the E.C.B. supervision requirement as a proxy for systemic relevance, is the negative highly statistical significance of the size indicating that for smaller banks the subordinated debt funding option is more convenient compared to bigger banks.

What is constant throughout all the regressions in Regression Table 1 Appendix is the remarkably high (99.9\% level), though conflicting, significance of two different profitability ratios, namely the "Return on Average Assets - R.O.A.A." and the "Return on Average Equity - R.O.A.E.". In particular, a higher R.O.A.A. is positively correlated with a higher ratio of subordinated debt, while R.O.A.E. is negatively correlated with subordinated debt ratio. Hence, the profitability of the bank is an important argument for issuing subordinated debt: only the above-average performing banks can afford to release a high level of subordinated debt, but still if a bank is highly capitalized (which leads to a high ROAE) the level of subordinated debt decrease. Thus, between equity and subordinated debt, a certain degree of substitutability seems to exist, on top of the regulatory capital threshold.

Finally, another variable which is constantly highly statistically significant and with positive parameter throughout the regressions (always at 99.9\% level) is the ratio between loans and assets. Hence, issuing subordinated bonds is a common way to fund, at least in part, marginal loans over the average level of the sample. That represents a crucial contingency since the credit crunch has been considered one of the primary determinates of the Italian (and more generally European) economic stagnation after the global financial crisis; consequently, this finding turns out to be particularly dense of policy implications. ${ }^{72}$

Some of those findings are of particular interests, and their policy implication will be analyzed later on in this chapter. However, to make this

72 The equations which comprehend all the variable categories prove to fits particularly well to the data, explaining the $50 \%$ and $75 \%$ of variations, respectively for financial structure and regulatory capital structure decisions. 
analysis as accurate as possible, some further insights can be added thanks to the second and third models introduced in the previous paragraph.

The fact that the high-level subordinated debt issuers have both higher loan-to-asset-ratio and lower N.P.L.-ratio is striking. In fact, for an institution with lower borrowing opportunities is expected to exert a more careful evaluation of the marginal loans, therefore resulting in a lower N.P.L.ration. A possible explanation is that subordinated debt holders actually monitor better what is going on in the bank, resulting in better choices about marginal borrowers. This is somehow in line with the study carried out by Sironi in $2003 ;^{73}$ nevertheless, it is in contrast with the actual identity of debt holder underlined in $\S 3$, mostly non-professional retail investors. A plausible alternative explanation is that the correlation between N.P.L. and level of subordinated debt entails a better risk taking by the management of the bank which is determined by unobservables (i.e.: variables that are not included in the statistical analysis). This latter explanation, even though it falls out of the model hereby proposed, seems to be more plausible.

For what concerns the variations over time (Regression Table 2 in Appendix), the regressions show pretty different pictures for the decisions about financial and regulatory capital structure. The latter has an irregular and not always significant path in the first years of the time series, while the coefficient of 2013 and 2014 are highly statistically significant, positive and big in magnitude. Those years were crucial for the implementation of new European Banking framework, with the entrance into force of C.R.D. IV/C.R.R., the proposals of the new Banking Union and the document about Burden Sharing in banking crisis. This evidence confirms the arguments of Chapter $\S 3$ about the role of subordinated debt as a cushion to protect senior creditors.

On the other hand, in the decision about financial structure, the most notable outcome of the time dummy model is the highly statistically significant increase in subordinated debt share during the hardest years of the global financial crisis (2008-2010).

${ }^{73}$ Sironi, supra note 19. 
Finally, the regressions shown in Table 7 give a perspective on the investor's point of view when deciding whether to invest in banks subordinated bonds or in something else.

Consistently with common sense and basic economic theory, the higher the class of regulatory capital (i.e.: the greater the loss absorbency capacity of the financial instrument), the higher the yield of the bond. What is less intuitive is that the bond rating variable has the expected negative coefficient though is not statistically significant. The same can be said for the N.P.L. ratio, meaning that investors relied on other types of information or, simpler, on the implicit guarantee of the domestic sovereign. Thus, those regressions perfectly depict the past but have a (hopefully) small capacity to predict what is going to happen in the future, since the old paradigm generates some biases in the regressions.

Nevertheless, there are two elements that are likely to hold even in the future: firstly, the profitability and size of the banks will remain an argument in investor's decisions. Secondly, there is a highly significant but slight cost advantage for bigger issues, which are usually adopted by larger banks, consistently with the findings by Santos (2014). On the other hand, there is a highly significant and substantial negative correlation between yield and bank profitability (measured through R.O.A.A.) which still have a straightforward explanation.

Another intuitive finding, useful to confirm the consistency of the model, is shown in the time series, where the yield of subordinated bonds increased significantly in 2008, when the global financial crisis broke out and, only for the bond spread, in 2011 when the public debt crisis began.

\subsection{POLICY CONSEQUENCES}

The findings of the present empirical analysis lead to one main policy conclusion, namely: agreeing with I.M.F. in supporting subordinated debt as a 
powerful tool to increase the soundness and resolvability of banking institutions. ${ }^{74}$

In fact, summarizing the evidence shown by the models, the banks that are more likely to issue a high share of subordinated debt (i.e.: finding it a convenient funding decision) are the medium-small banks, which are not systemically relevant and whose level of performance is above average. Given those arguments, creating an institutional framework which is "subordinateddebt-friendly" seems to foster efficiency. Moreover, it is also consistent with the goal of generating a level playing field among European banks as well, reducing the cost-advantage in complying with more requesting regulatory framework joined by bigger banks. 75

On the other hand, there is no evidence that the act of issuing subordinated bonds itself leads to moral hazard or adverse selection. In fact, issuing subordinated debt can lead to an inefficient outcome if: the supervisory activity is suboptimal, the implicit guarantee of the sovereign on bank solvency still exists, and the enforcement of the subordination clause through resolution tools is uncertain. Assuming an optimal suspensory activity, ${ }^{76}$ the implicit guarantee that characterized the last decades should not exist anymore in the new institutional framework; ${ }^{77}$ what remains a problem is the level of certainty in enforcement mechanism. This issue will be specifically tackled in Chapter $\S$ 5.

Beyond the arguments already discussed, previous empirical findings allow to add two other important aspects supporting the use of subordinated bonds in banks financing. First of all, issuing subordinated debt signals the market that the bank has the appropriate level of soundness to go to the market and sell those bonds at a reasonable price. Second of all, and more important, the higher the level of issued subordinated bonds the higher the level of loans granted. Such a contingency should be highly relevant for the

\footnotetext{
74 Davies, supra note 13, at 512.

${ }^{75}$ As proved by SANTOS, supra note 66.

${ }^{76}$ That is quite an unrealistic assumption, even though the S.S.M. reform improved the quality of supervision toward Eurozone Banks. See FERRARINI, Guido A. Single Supervision and the Governance of Banking Markets. ECGI-Law Working Paper, 2015, 294.

77 Still, this assumption is not completely true since B.R.R.D. leaves a certain room for bail-outs intervention: Council Directive 2014/59, art 100, 2014 O.J. (L 173). Nonetheless, for the sake of this analysis this represents a workable assumption.
} 
European policy makers since there is a broad consensus in considering the credit crunch as one of the crucial determinants of the prolonged economic stagnation of Eurozone..$^{78}$

Chapter 3 showed that current institutions (both formal and informal institutions and their enforcement mechanisms) might lead to a lack of incentives to issue subordinated bonds. Then, this Chapter strengthens the arguments in favor of desirability for a dynamic market for subordinated bonds. Hence, the last step of this paper will be devoted to proposing an institutional framework with an enhanced degree of certainty in the enforcement (i.e.: resolution) phase.

\section{CONVERTIBLE SUBORDINATED BOND: A SOLUTION THROUGH CONTRACTS?}

Given the uncertainty and unpredictability underlined in the previous sections, the question arising is whether the current institutional framework furnishes efficient incentives to all the relevant agents to foster the resilience of the bank. Borrowing from Douglas North:79 is the institutional matrix providing a pay-off matrix which leads the actors to act efficiently?

To answer this question, the outcome of the empirical study carried out in Section $\S 4$ has to be combined with some other insights about bail-in in general. First of all, under Article $37 \S 10$ sub. a, any sort of bail-out operations become lawful if and only if at least the of $8 \%$ of the bank's liabilities were written down. Some scholars ${ }^{80}$ predicted the tendency to prefer a "private bailout solution" right after the $8 \%$ threshold has been reached. "Private bail-out" solutions indicate all the available mechanisms providing external funds to the distressed bank without a direct State intervention or a market operation. ${ }^{81}$

\footnotetext{
${ }^{78}$ Juan R. Cuarado-Roura, Ron Martin \& Andrés Rodrìguez-Pose, The economic crisis in Europe: urban and regional consequences, 9 CAMBRIDGE J. REGIONS, ECON. AND SOC'Y 3 (2016).

79 Duglas C. North, Institutions and the performance of economies over time, in HANDBOOK OF NEW INSTITUTIONAL ECONOMICS 21-30 (2008).

${ }^{80}$ Goodhart \& Avgouleas, supra note 7, at 20; MCANDREWS, supra note 46.

${ }^{81}$ Council Directive 2014/59, supra note 77, art. 100 and ff.
} 
In the second place, the fact that during the 2007-08 crisis the losses of the distressed banks were in average, around $8 \% .{ }^{82}$ Thus the expected outcome in a 2007 crisis scenario with the new regulatory framework can be depicted as follows: the new regulation determines the need to bail-in the $8 \%$ of distressed banks liabilities; therefore, subordinated debt will act, in practice, as a cushion to protect senior creditors.

Piecing all these aspects together, subordinated bondholders suffer a high uncertainty about their investment, and they cannot correctly ex-ante assess this risk. In fact, the investors do not only face the risk of bank insolvency, but also the risk to be bailed-in by the resolution authority, according to the non-strictly quantitative trigger events of Article 32. Thus, the predictable outcome is to overestimate the risk, asking for an abnormally high yield and subsequently reducing the scope of subordinated bond market, as the Italian case depicted in Section $§ 3$ suggests.

To make the investment in subordinated bonds feasible for both banks and investors, this Section proposes a contractual solution setting a trigger event to convert or write-down the creditors' claim, tailored upon the model offered by "Contingent Convertible" bonds. In fact, subordinated bonds seem to be pretty attractive for both investors and several banks; moreover, they turn to be important even from the resolution authority's standpoint, ${ }^{83}$ to protect senior creditor from bail-in and, hence, safeguarding some degree of trust within the banking system.

While the issue of certainty in subordinated bond investments is still without an answer, two recent proposals for amending B.R.R.D. could somehow change the role of subordinated debt as a cushion of senior creditors. In fact, the European Commission issued two proposals of Directive amending the B.R.R.D. in order to implement T.L.A.C. requirements. ${ }^{84}$ What is of interests for

${ }^{82}$ Conlon \& Cotter, supra note 24; See also Paolo Santella et al., Il Nuovo Regime Europeo Di Risoluzione Delle Crisi Bancarie: Un'Analisi Comparata Dell'Applicazione Del Bail-In [A Comparative Analysis of the Bail-In Regime in Europe], 9 BANCARIA 46-62 (2015).

${ }^{83}$ Davies, supra note 13, at 512.

${ }^{84}$ Commission Proposal for a DIRECTIVE OF THE EUROPEAN PARLIAMENT AND OF THE COUNCIL Amending Directive 2014/59/EU on Loss-Absorbing and Recapitalisation Capacity of Credit Institutions and Investment Firms and Amending Directive 98/26/EC, Directive 2002/47/EC, Directive 2012/30/EU, Directive 2011/35/EU, Directive 2005/56/EC, Directive 2004/25/EC and Directive 2007/36/EC, COM (2016) 852 final (Nov. 23, 2016); and Commission Proposal for a DIRECTIVE OF THE EUROPEAN PARLIAMENT AND OF THE COUNCIL on Amending Directive 
the present paper is the proposal to establish an intermediate class of bailinable liabilities which lies in between subordinated and senior debt, as of hierarchy of creditors' claim. The "new class" of creditors could be written down only during a formal resolution intervention and not with a plain ongoing write-down. The purpose of the proposal is helping banking institutions to match the T.L.A.C. requirement at a reasonable price, protecting senior creditor creditors even further.

On the one hand, those proposed amendments are consistent with and even confirm - the main idea carried out in this paper, i.e.: de jure condito, subordinated liabilities act as a cushion for protecting senior creditors. On the other hand, as noticed above, the main problem that has been identified in the paper (i.e.: uncertainty) is not solved, but just shifted and pooled between two different classes. Thus, the prospective implementation of those proposals will not falsify the arguments of this study, which should just be accordingly reshaped.

For those reasons, the analysis that follows is carried out de jure condito, i.e.: without taking into consideration the possible changes if the latter proposal will be implemented

The following sub-section provides an introduction to the idea of contractual bail-in in the literature and the current institutional framework; eventually, that same framework will be compared with the conditions under which a contractual arrangement is a value-creating institution in the classic law and economics sense. ${ }^{85}$

\subsection{CONTRACTUAL CLAUSE FOR WRITING DOWN AND CONVERSION: A PROBLEM SOLVING TOOL}

Literature about contractual clauses to convert debt into equity, and thus enhance capital stability and bank resilience, is extensive and precede the global financial crisis, ${ }^{86}$ even if the concrete applications are few and

2014/59/EU of the European Parliament and of the Council as Regards the Ranking of Unsecured Debt Instruments in Insolvency Hierarchy, COM (2016) 853 final (Nov. 23, 2016).

${ }^{85}$ See Robert COOTER \& THOMAS Ulen, LAW AND ECONOMics 283 (6th ed., 2011).

86 See Mark J. Flannery, No Pain, No Gain? Effecting Market Discipline via "Reverse Convertible Debentures", in CAPITAL ADEQUACY BEYOND BASEL: BANKING, SECURITIES, AND INSURANCE 171 (2005). 
ambiguous in their results. ${ }^{87}$ This mechanism is usually labeled as "Contingent Capital Instruments" or "CoCo Bonds". A major distinction is drawn between high-trigger and low-trigger instruments, where the event that triggers the conversion for the former is to reach the minimum capital requirement, while for the latter the trigger point is set to a higher level of capital ratio.

Coffee $^{88}$ approaches contingent capital as a tool to avoid the necessity to bail-out banks and, at the same time, to preserve the financial stability of the banking system, which - in his view - would be threatened by a pure bail-in scenario. Thus, the mandatory contingent capital regime is seen as a substitute and not as a complement of the bail-in mechanism.

Even though this approach is far from the position of the present paper, some aspects underlined by Coffee are of utmost interest. High-trigger contingent capital instruments allow banks to create adequate "potential" capital buffers, increase the level of certainty of investments and have a tax advantage over the "raise more equity" option.

In contrast with the latter approach, Tucker incisively noticed: "Today, Cocos with decently high triggers are likely to be prohibitively expensive . . . . Eventually, I can conceive that Cocos with highish triggers might be issued as a means for the market to maintain control of its own destiny in the shadow of resolution". ${ }^{89}$

This scenario acquired a new and broader meaning with the entrance into force of the post-crisis resolution frameworks. The issuance of Cocos must happen "in the shadow of resolution", which means that the contingent capital instruments are - by definition - a complement and not a substitute of bail-in mechanism, so the Coffee's model is entirely overturned, at least in the Eurozone.

The B.R.R.D. provides two foremost normative references to the role of contractual clauses in the bail-in process. Article 55 deals with the typical case where the bonds are issued under a non-E.U. applicable law (e.g.: bonds issued

${ }^{87}$ See Carolin E. Schmidt, Ted F. Azarmi, The Impact of CoCo Bonds On Bank Value And Perceived Default Risk: Insights And Evidence From Their Pioneering Use In Europe, 31 J. APPLIED Bus. Res. 2297 (2015).

${ }^{88}$ COFFEE, John. Bail-ins versus bail-outs: using contingent capital to mitigate systemic risk. Columbia Law and Economics Working Paper, 2010, 380.

89 Tucker, supra note 23 , at 8 . 
under the New York State law are quite common), asking for a contractual recognition of the power of conversion and write-down. This aspect is crucial to make bail-in effective since one of the biggest problems in previous resolution attempts were exactly the cross-border issues. $9^{90}$

Even more interesting for this paper is Article 45 (13) and (14) about M.R.E.L. ${ }^{91}$ : this can be reached issuing debt instruments with contractual clause for conversion and write-down, following two conditions:

-The Resolution Authority is free to write down or convert the contractual instrument in case of resolution;

-The contractual clause is applied to a subordinated debt instrument.

So, the B.R.R.D. only keeps the possibility of contractual bail-in open, on the contrary of the Swiss Regulator which impose a mandatory 3\% R.W.A. of hightrigger $\operatorname{Cocos}^{92}$.

Davies $^{93}$ noticed how such a clause would reverse the hierarchy in bearing losses, meaning that subordinated creditors bear losses before shareholders. This contingency seems to contrast with all the three principals of creditor treatment stated by Article 34 B.R.R.D., confirming again that it provides only disposable rights which generate ex post legal remedies (i.e.: liability and not property rules).

\subsection{INCENTIVE STRUCTURE OF RELEVANT ACTORS}

Given all the background information of $\S 5.1$, the last question has still to be answered: "Is the institutional framework depicted in the previous paragraph giving adequate incentives to all the relevant actors?". In order to properly answer, the relevant variables discussed in this section are four: the incentives of the management, the role of resolution authority, the desirability of ex-ante

\footnotetext{
${ }^{90}$ Gleeson, supra note 9 , at 274 .

${ }^{91}$ See European Banking Authority, Interim report on MREL, EBA-Op-2016-12, at 76 (Jul. 19, 2016).

${ }^{92}$ Stefan Avdjiev, Anastasia V. Kartasheva \& Bilyana Bogdanova, CoCos: a primer, BANK INT'L SETTLEMENT QUARTERly ReV., Sept. 2013, at 43. See AVDJIEV, Stefan; KARTASHEVA, Anastasia V.; BOGDANOVA, Bilyana. CoCos: a primer. Available at SSRN 2326334, 2013.

${ }_{93}$ Davies, supra note 13, at 511.
} 
rights (i.e.: governance power) to bondholders; the trigger event and conversion formula.

1) Management: the fundamental aspect to be analyzed is whether the issuance of subordinated debt with contractual bail-in clause incentivizes the incumbent management to assume opportunistic behaviors or excessive risk taking.

For what concerns opportunistic behavior, the underlying assumption is that in a non-strategic environment - the decision to issue subordinated debt is a function of the resolution authority conduct. Even though this assumption does not fully hold in the real world, for this analysis it represents a workable proxy.

Article 28 B.R.R.D. provides the possibility to remove the incumbent management "where there is a significant deterioration in the financial situation", while Article 34 § 1 (c) set as a general principle of each resolution intervention the dismissal of the incumbent board. In case of contractual conversion/write-down, the application of Article 34 is highly unlikely, so that the contractual write-down instruments act as a costly insurance paid by the bank to avoid a proper resolution intervention, hence their dismissal. To avoid such a risk, the threat set by Article 28 has to be credible, since the contractual conversion/write-down, even if it is not a proper resolution intervention, is still a "resolution-sensitive" occurrence.

For what concerns excessive risk taking, the arguments stated above can be replicated. Moreover, as the empirical evidenced in $\S 4$ showed, the issuance of subordinated bonds is correlated both with higher loan-to-assetratio and lower N.L.P.-ratio. In a hypothetical scenario where the certainty about the subordinated bonds is enhanced, there is no reason to suspect that those evidence would be reversed.

In a nutshell, the formal institutional framework theoretically allows giving suitable incentive to the management if and only if the enforcement mechanism works efficiently.

2) Resolution Authority: the role of the Resolution Authority is perhaps the most important one. From this perspective the formal institutions seem to 
be severely lacking, since the only direct provision on contractual clauses is Article 45 (13) and (14), where is stated the abstract possibility to issue those instruments to reach the M.R.E.L.. The bank and the investor enter into a contract and, at the same time, a third party (the Resolution Authority) might affect a great deal the situation that the contract aims to discipline. In this situation, there is no or very little room for a cooperative solution (i.e.: conclude the deal) since the payoff matrix is highly unpredictable.

A possible settlement for this problem is to make the Resolution Authority enter somehow into the agreement. The easiest and cheapest way to do so would be to submit the issuance contract to the resolution authority and ask for its formal inclusion in the resolution plan, ${ }^{94}$ stating that the terms of the contract are consistent with a sound resolution planning and, thus, will be respected by the Authority in case of future interventions. This solution would also help to ex-ante mitigate the risk of strategic issuance of the management since the Resolution Authority shall control the consistency of the issuance with the safe and soundness of the banking institution in an on-going concern.

3) Investors: as noted above, because of the contractual bail-in clause, the investors give up some of the rights provided by the Article 34 of the Directive. Thus, granting some ex-ante "property" protection could seem reasonable.95 A pragmatic approach suggests avoiding the creation of welldesign but too complicated and ineffective mechanisms to let subordinated creditors protect ex-ante their entitlement. In fact, the effectiveness of the shareholder's empowerment rights is ambiguous, and the possibility to enhance the corporate governance in the case of subordinated bondholders is limited. Therefore, the transaction costs generated by introducing those rights are particularly likely to outweigh some, uncertain and unpredictable, benefits. ${ }^{96}$

94 For what concerns the crucial role of resolution planning, which was not possible to properly describe throughout this paper, see Binder, 2015.

95 For example including in the contract some powers modeled on the rights granted to shareholders to empower their position vis-à-vis the board. On shareholder's empowerment, see Van Der Elst, 2014:30-33 and Denes et al., 2016.

96 Those arguments hold for what specifically concerns the case for contingent convertible holder. A completely different scenario can be depicted in general for the need of corporate governance rights to bail-inalble creditors after B.R.R.D. On those issue see extensively Mülbert, P. O., \& Citlau, R. D. (2011). The uncertain role of banks' corporate governance in systemic risk regulation. ECGI-Law Working Paper, (179) Chiu, I. H. (2014). Corporate governance: the missing 
Even though giving specific substantive rights turn out to be ineffective and too expensive, this does not mean that there is absolutely no room for some recognition of the "contractual bail-in bondholder" status, at least from a procedural perspective. In fact, this type of investors should be recognized as an independent class, expressively allowing them to act collectively. This represents a value-creating device since it gives more contractual power to the investors, which will be incentivized to enter into the contract because of decreasing transaction costs, at least in two contingencies:

i) before and regardless any resolution intervention, in case of renegotiation of the contract (savings in bargaining costs);

ii) after a resolution in suing the bank to obtain a compensation (savings in enforcement costs).

From this point of view, the European institutional framework seems to be completely lacking. In fact, a uniform procedural rule for civil justice are far to be reached within the European Union nor specific rules concerning these issues are provided by the Directive. Thus, the concrete configuration of the investors' rights and claims is devolved to national laws, undermining the "level playing field" among E.U. countries, which is one of the primary goals of the B.R.R.D.. ${ }^{97}$

4) Trigger Event and Conversion Formula: represents the most awkward clause of the contract for convertible subordinated bonds. Indeed, most of the Contingent Capital literature focuses on this instance developing elaborated theoretical models. ${ }^{98}$ In this paper is not possible to add any contribution to such a complex and technical dispute. Anyhow. what is of interest here is whether the current institutional framework allows and incentivize to adopt the efficient solution.

The answer seems to be positive since neither the Directive nor the Guideline on the trigger event ${ }^{99}$ or conversion rate ${ }^{100}$ forbids to agree on a

paradigm in the mandatory bail-in regime for creditors of banks and financial institutions. Journal of Business Law, (8).

97 See Council Directive 2014/59, recital 57, 108, 2014 O.J. (173).

${ }^{98}$ For a survey, see Glasserman, P., and Nouri, B. (2012). Contingent capital with a capital-ratio trigger. Management Science, 58(10), 1816-1833.

99 European Banking Authority, Final Report, Draft Regulatory Technical Standards on the contractual recognition of write-down and conversion powers under Article 55(3) of Directive 
tailored solution, with the external limit of respecting the bail-in principle stated in Article 34, leaving to the market any further consideration. Nonetheless, to incentivize the investors to enter into those contracts and to give the market appropriate signals, the conversion formula should favor the creditors and burden shareholders. ${ }^{101}$ The potential (plausible) negative externalities of some specific kind of trigger event shall be addressed by the regulator in its "intervention", as proposed above, under n. 3.

The signaling effect is of particular importance both for creditors and the market in general. In fact, a conversion of debt into equity means a dilution in shareholders' cash flows, and likely in management's ones as well. Thus, a bank willing to issue those bonds with a decently high trigger and with a creditor-favorable conversion formula signal to the market and the perspective bondholders its soundness.

\section{CONCLUSION}

Throughout this study has been demonstrated - theoretically and empirically - that, following F.S.B. position, the existence of an active and functioning market for subordinated bonds enhance the soundness and the resolvability of banking institutions, especially of the medium-small ones. In fact, the cost advantage in raising funds of systemically important banks is reduced, and thus level playing field within European banking market is enhanced.

The new regulatory framework for capital requirements and resolution of distressed institutions lead to tremendous changes in the market for subordinated bonds, both in their demand, supply and pricing mechanism. As a consequence, both banks and investors have to internalize all the costs and risks linked with subordinated bond; which is - at least theoretically particularly desirable to incentivize more efficient decisions on funding decision, to avoid moral hazard and strategic behavior by both banks and

2014/59/EU, EBA/RTS/2015/06, (Jul. 3, 2015).

100 European Banking Authority, Consultation Paper, Draft Guidelines Concerning the Interrrelationship Between the BRRD sequence of writedown and conversion and CRR/CRD IV, EBA/CP/2014/29, (Oct. 1, 2014).

${ }^{101}$ COFFEE, supra note 88 , at 35. 
investors and, consequently, to enhance market discipline capacity of the secondary market.

Nevertheless, due to the concrete bank's financial structure and bail-in regulation, the subordinated debt in resolution, and especially if the Authority resorts to the bail-in tool, assumes the peculiar role of a cushion that allows protecting senior creditors from conversions or dilution in their claims. This leads to a high level of uncertainty in the enforcement of the subordination clause, which endangers the functioning of a market for subordinated bond.

On the other hand, the empirical analysis carried out sub $\S 4$ clearly showed the desirability of a well-functioning market for subordinated bonds, especially for its positive correlation with the lower level of N.P.Ls. and the higher level of loans over assets, i.e.: weakening the credit crunch.

In a nutshell, the current institutional framework appears not to be able to give the appropriate incentives to both investors and banks to issue the right amount of subordinated bonds. Therefore, this paper concludes that a plain mandatory conversion and write down of subordinated debt does not achieve an efficient outcome because of the spillover effects that these rules have on subordinated debt market on a dynamic perspective. To fix those spillover effects and maintain all the positive innovation led by bail-in regulation, this paper proposes the adoption of a "contractual bail-in" regime, tailored on the contingent capital model.

Finally, the paper shows the condition under which the "contractual bail-in" solution turns out to be appealing to banks and investors and, at the same time, desirable from the regulator's standpoint, i.e.: the contractual solution enhance the soundness and resolvability of the regulated institutions. Even though all the actors are involved in the analysis, the role of the supervisory and resolution authorities in abstaining to infringe and protecting the property rights allocated by the contract is the first, necessary, condition to reach an efficient outcome and to balance as well as possible all the interests involved. 


\section{APPENDIX}

Variables list

\begin{tabular}{|c|c|}
\hline Rating & $\begin{array}{l}\text { From Thomson Reuters. It measures the rating (if } \\
\text { available) for each bond. We relied on three different } \\
\text { rating agency: Moody's, Fitch and S\&P, according to the } \\
\text { availability of complete data for the time series. The } \\
\text { ratings are encoded to make them comparable, } \\
\text { according to the conversion table published in BIS. See } \\
\text { http://www.bis.org/bcbs/qis/qisrating.htm. The higher } \\
\text { the code assigned, the higher the rating. }\end{array}$ \\
\hline Coupon & $\begin{array}{l}\text { From Thompson Reuters. This variable can be } \\
\text { continue or vary over time depending whether the } \\
\text { bond provides for fixed, variable or floating coupon. }\end{array}$ \\
\hline Bond Spread & $\begin{array}{l}\text { Own calculation. Underlying variables from Thomson } \\
\text { Reuters. The spread between the secondary market } \\
\text { yield of each bond and the secondary market yield of } \\
\text { 10-year Italian governmental bond. The 10-yaer bond } \\
\text { is taken as a benchmark since the duration mean of } \\
\text { the subordinated bonds is over nine years, so the 10- } \\
\text { year bond represents a significant benchmark. }\end{array}$ \\
\hline Volume & $\begin{array}{l}\text { From Thomson Reuters. The amount in mil } € \text { of the } \\
\text { issue calculated in the issue date and invariant over } \\
\text { time. }\end{array}$ \\
\hline Class of Capital & $\begin{array}{l}\text { From Thomson Reuters and Pillar } 3 \text { documents. } \\
\text { Categorical variables which describe the class of } \\
\text { regulatory capital to which the bond belongs. The } \\
\text { available possibilities are Additional Tier 1; Tier 2; Low } \\
\text { Tier } 2 \text { for Basel II agreements, now under the } \\
\text { Grandfathering clause during the transitory period; } \\
\text { not belonging to regulatory capital. }\end{array}$ \\
\hline
\end{tabular}




\begin{tabular}{|c|c|}
\hline E.C.B. supervision & $\begin{array}{l}\text { From SSM website. Dummy variable describing } \\
\text { whether the bank is under the direct supervision of } \\
\text { the E.C.B. (in this case the value } 1 \text { is assigned). It } \\
\text { measures whether the threshold provided by SSM } \\
\text { regulation are significant but still say nothing about } \\
\text { the impact of E.C.B. supervision since it started only } \\
\text { two years ago. }\end{array}$ \\
\hline Capital Ratio & $\begin{array}{l}\text { From BankScope. The ratio between total regulatory } \\
\text { capital and total liabilities. }\end{array}$ \\
\hline Tier 1 ratio & $\begin{array}{l}\text { From BankScope. Ratio Between Tier } 1 \text { Capital and } \\
\text { total liabilities }\end{array}$ \\
\hline $\mathrm{n}^{\circ} \mathrm{com}$ & $\begin{array}{l}\text { From BankScope. Number of financial and non- } \\
\text { financial company controlled by the parent bank. It is } \\
\text { used as a proxy of the complexity of the banking } \\
\text { group. }\end{array}$ \\
\hline $\begin{array}{l}\text { Return on Average } \\
\text { Assets }\end{array}$ & $\begin{array}{l}\text { From BankScope. Measure the profitability of the } \\
\text { bank. It is defined as the ratio between income and the } \\
\text { average amount of assets. }\end{array}$ \\
\hline $\begin{array}{l}\text { Return on Average } \\
\qquad \text { Equity }\end{array}$ & $\begin{array}{l}\text { From BankScope. Measure the profitability of the } \\
\text { bank. It is defined as the ratio between income and the } \\
\text { average amount of common shares. }\end{array}$ \\
\hline Total assets (log) & $\begin{array}{l}\text { From BankScope. Total asset accounted on the balance } \\
\text { sheet. }\end{array}$ \\
\hline N.P.L. ratio & $\begin{array}{l}\text { Own calculation. Underlying variables from } \\
\text { BankScope. The ratio between substandard loans and } \\
\text { total net loans. In building the variables we used } \\
\text { "substandard loans" for the sake of pragmatism, since } \\
\text { it was the only component of N.P.L. for which data } \\
\text { where available throughout all the sample. Anyhow, } \\
\text { substandard loans and the other component of N.P.L. } \\
\text { are highly correlated; thus this variable is completely }\end{array}$ \\
\hline
\end{tabular}




\begin{tabular}{|cl}
\hline Loans over assets & reliable. \\
& $\begin{array}{l}\text { From BankScope. Describe the relative amount of } \\
\text { loans granted by each bank. }\end{array}$ \\
Sub. debt over & From BankScope. Describe the ratio between the \\
regulatory capital & amount of issued subordinated debt and total \\
& regulatory capital. We use this variable as dependent \\
& to investigate the determinants of decision about \\
& capital structure for what concerns issuing \\
Sub. debt over total & Own calculation. underlying variables from \\
liabilities & $\begin{array}{l}\text { BankScope. Describe the ratio between the amount of } \\
\text { issued subordinated debt and total liabilities on } \\
\text { balance sheet We use this variale as dependent to } \\
\text { investigate the determiants of decision about financial } \\
\text { structure for what concerns issuing subordinated debt. }\end{array}$
\end{tabular}


Regression Table 1

\begin{tabular}{|c|c|c|c|c|c|c|c|c|}
\hline & \multicolumn{4}{|c|}{ Subordina ted debt over liabilities } & \multicolumn{4}{|c|}{ Subordinated debt over regula tory capital } \\
\hline & 1 & 2 & 3 & 4 & 5 & 6 & 7 & 8 \\
\hline \multicolumn{9}{|l|}{ Class of } \\
\hline \multirow[t]{2}{*}{ capital } & $0.105^{*}$ & & & 0.0780 & $-0.548^{* * *}$ & & & $-0.288^{* * * *}$ \\
\hline & $(2.01)$ & & & $(1.85)$ & $(-4.31)$ & & & $(-4.01)$ \\
\hline \multicolumn{9}{|l|}{ Ecb } \\
\hline \multirow[t]{2}{*}{ supervision } & $-0.875^{* *}$ & & & 0 & 0.152 & & & -0.114 \\
\hline & $(-3.01)$ & & & (1) & $(0.45)$ & & & $(-0.68)$ \\
\hline \multirow[t]{2}{*}{ Capital ra tio } & $0.318^{* * *}$ & & & $0.204 * * *$ & 0.0246 & & & 0.0741 \\
\hline & $(14.58)$ & & & $(4.19)$ & $(0.50)$ & & & $(1.95)$ \\
\hline \multirow[t]{2}{*}{ Tier1 ratio } & $-0.318^{* * *}$ & & & $-0.235^{* * *}$ & $-0.00126^{*}$ & & & 0.000485 \\
\hline & $(-12.60)$ & & & $(-3.75)$ & $(-2.05)$ & & & $(1.76)$ \\
\hline \multirow[t]{2}{*}{ Ra ting } & & -0.00524 & & -0.00476 & & -0.338 & & -0.568 \\
\hline & & $(-0.37)$ & & $(-0.40)$ & & $(-0.67)$ & & $(-1.82)$ \\
\hline \multirow[t]{2}{*}{ Coupon } & & $0.0842^{*}$ & & 0.00000912 & & $-5.370^{*}$ & & 0 \\
\hline & & $(2.51)$ & & $(0.00)$ & & $(-2.25)$ & & (1) \\
\hline \multirow[t]{2}{*}{ Bond spread } & & -0.00103 & & 0.00409 & & $2.649 * * *$ & & $2.517^{* * *}$ \\
\hline & & $(-0.17)$ & & $(1.06)$ & & $(13.83)$ & & $(8.04)$ \\
\hline \multirow[t]{2}{*}{ volume } & & -0.000000504 & & $0.000158^{* *}$ & & $-2.517^{* * *}$ & & $-2.749 * * *$ \\
\hline & & $(-0.01)$ & & $(2.70)$ & & $(-14.05)$ & & $(-6.59)$ \\
\hline \multirow[t]{2}{*}{$N^{\circ}$ companies } & & & 0.0000180 & -0.0000653 & & & 0.000541 & -0.0000662 \\
\hline & & & $(0.27)$ & $(-0.66)$ & & & $(1.18)$ & $(-0.11)$ \\
\hline \multirow[t]{2}{*}{ ROAA } & & & $0.348^{* * *}$ & $0.249 * * *$ & & & $5.197^{* * *}$ & $4.778^{* * *}$ \\
\hline & & & $(5.92)$ & (3.85) & & & $(8.66)$ & $(9.58)$ \\
\hline \multirow[t]{2}{*}{ ROAE } & & & $-0.0206^{* * *}$ & $-0.0105^{* *}$ & & & $-0.441 * * *$ & $-0.362^{* * * *}$ \\
\hline & & & $(-7.22)$ & $(-2.59)$ & & & $(-15.98)$ & $(-12.66)$ \\
\hline \multicolumn{9}{|l|}{ Totalassets } \\
\hline \multirow[t]{2}{*}{$(\log )$} & & & -0.0798 & -0.126 & & & $-1.399 * * *$ & $-1.680^{*}$ \\
\hline & & & $(-1.36)$ & $(-1.31)$ & & & $(-3.35)$ & $(-2.52)$ \\
\hline \multirow[t]{2}{*}{ N PLra tio } & & & 0.00112 & $-0.00810^{*}$ & & & 0.0295 & -0.0233 \\
\hline & & & $(0.57)$ & $(-2.40)$ & & & $(1.64)$ & $(-0.65)$ \\
\hline \multicolumn{9}{|l|}{ Loans over } \\
\hline \multirow[t]{2}{*}{ assets } & & & $0.0282 * * *$ & $0.0258^{* * *}$ & & & $-0.161^{* * * *}$ & $-0.170^{* * *}$ \\
\hline & & & $(4.69)$ & $(4.08)$ & & & $(-3.72)$ & $(-3.34)$ \\
\hline N & 621 & 273 & 621 & 273 & 273 & 621 & 621 & 273 \\
\hline \multicolumn{9}{|l|}{ adj. R-sq } \\
\hline within & & & & 0,3758 & & & & 0,5516 \\
\hline between & & & & 0,6023 & & & & 0,8621 \\
\hline overall & & & & 0,4982 & & & & 0,7545 \\
\hline
\end{tabular}

Regression table on financial structure and regulatory capital structure decision and subordinated debt. Regressions are run with the random effect estimation method and robust error to avoid heteroskedasticity; $\mathrm{t}$-statistic in parenthesis. $*, * *$ and $* * *$ denote statistical significance at the $5 \%, 1 \%$ and $0,1 \%$ levels, respectively

The same independent variables are used to explain two different dependent variables which aim to describe the two distinct aspects above- 
mentioned, respectively: 'subordinated debt over total liabilities' and 'subordinated debt over regulatory capital' according to the models in equations (1) and (2):

(1) SubDebt/TotLiabilities $=\mathrm{a}_{0}+\mathrm{a}_{1} \boldsymbol{\Sigma} \mathrm{V}^{\text {Bank }_{\mathrm{i}, \mathrm{t}}}+\mathrm{a}_{2} \boldsymbol{\Sigma} \mathrm{V}_{\text {Bond }_{\mathrm{i}, \mathrm{t}}+\mathrm{a}_{3} \boldsymbol{\Sigma} \mathrm{V}^{\text {Regulation }}}{ }_{\mathrm{i}, \mathrm{t}}+\varepsilon_{\mathrm{i}, \mathrm{t}}$;

(2) SubDebt/RegCapital $=\mathrm{a}_{0}+\mathrm{a}_{1} \boldsymbol{\Sigma} \mathrm{V}_{\text {Bank }_{\mathrm{i}, \mathrm{t}}}+\mathrm{a}_{2} \boldsymbol{\Sigma} \mathrm{V}_{\text {Bond }_{\mathrm{i}, \mathrm{t}}}+\mathrm{a}_{3} \boldsymbol{\Sigma} \mathrm{V}^{\text {Regulation }}{ }_{\mathrm{i}, \mathrm{t}}+\varepsilon_{\mathrm{i}, \mathrm{t}}$;

where $\mathrm{V}^{\mathrm{Bank}}$ are the variables characterizing the issuing bank (number of companies belonging to the group; Return on Average Assets; Return on Average Equity; Total Assets; Non-Performing Loans ratio; Loans over assets ratio); $\mathrm{V}^{\text {Bond }}$ are the variables characterizing the individual bond issued (Coupon; Volume; Rating; Bond Spread), and V ${ }^{\text {Regulation }}$ are variables related to regulatory constraints on banking activity (dummy for class of capital; direct E.C.B. supervision; regulatory capital ratio; Tier 1 capital ratio).

The regressions are run both separately for each category of variable and, eventually, with all the variables together. 
Regression Table 2

\begin{tabular}{|c|c|c|}
\hline & $\begin{array}{l}\text { Subordinated debt over } \\
\text { total liabilities }\end{array}$ & $\begin{array}{l}\text { Subordinated debt over } \\
\text { regulatory capital }\end{array}$ \\
\hline & 1 & 2 \\
\hline 2006 & 0 & 0 \\
\hline & (.) & (.) \\
\hline 2007 & 0.203 & -0.601 \\
\hline & $(0.156)$ & -1.528 \\
\hline 2008 & $0.368 * * *$ & $1.251^{*}$ \\
\hline & $(0.0317)$ & $(0.583)$ \\
\hline 2009 & $0.355 * * *$ & $-1.107^{*}$ \\
\hline & $(0.0656)$ & $(0.560)$ \\
\hline 2010 & $0.209 * * *$ & -1.066 \\
\hline & $(0.0621)$ & $(0.585)$ \\
\hline 2011 & 0.0182 & $0.856^{*}$ \\
\hline & $(0.0358)$ & $(0.366)$ \\
\hline 2012 & -0.0780 & -0.156 \\
\hline & $(0.0513)$ & $(0.543)$ \\
\hline 2013 & 0.0302 & $2.134 * * *$ \\
\hline & $(0.0446)$ & $(0.554)$ \\
\hline 2014 & $0.146^{* *}$ & $3.312 * * *$ \\
\hline & $(0.0534)$ & $(0.715)$ \\
\hline 2015 & -0.0273 & 0.199 \\
\hline & $(0.0557)$ & $(0.444)$ \\
\hline $\mathbf{N}$ & 621 & 621 \\
\hline$R \cdot s q$ & & \\
\hline within & 0,0984 & 0,1097 \\
\hline etween & 0,0561 & 0,0152 \\
\hline overall & 0,0565 & 0,0523 \\
\hline
\end{tabular}

Regression table on financial structure and regulatory capital structure decision over time. Regressions are run with the fixed effect estimation method and robust error to avoid heteroskedasticity; $\mathrm{t}$-statistic in parenthesis. $*, * *$ and $* * *$ denote statistical significance at the $5 \%, 1 \%$ and $0,1 \%$ levels, respectively. 
This issue is addressed as shown in equations (3) and (4), utilizes a time dummy variable to observe whether there has been some significant variation as a result of the introduction of new regulations or economic shocks.

(3) SubDebt/TotLiabilities $=\mathrm{a}_{0}+\mathrm{a}_{1} \boldsymbol{\Sigma} \mathrm{D}^{\mathrm{time}}+\varepsilon_{\mathrm{i}, \mathrm{t}}$;

(4) SubDebt/RegCapital $=\mathrm{a}_{0}+\mathrm{a}_{1} \boldsymbol{\Sigma} \mathrm{D}^{\text {time }}+\varepsilon_{\mathrm{i}, \mathrm{t}}$; 
Regression Table 3

\begin{tabular}{|c|c|c|}
\hline & Bond Spread & Yield \\
\hline & 1 & 2 \\
\hline \multirow[t]{2}{*}{ Rating } & -0.241 & -0.241 \\
\hline & $(-179)$ & $(-179)$ \\
\hline \multirow[t]{2}{*}{ dass of capital } & $1.500^{\prime}$ & $1.509^{\prime}$ \\
\hline & (5.0) & $(5.01)$ \\
\hline \multirow[t]{2}{*}{ Volume } & $-0.00105^{*}$ & $-0.00105^{*}$ \\
\hline & $(-211)$ & $(-211)$ \\
\hline \multirow[t]{2}{*}{ NPLratio } & 0.115 & 0.115 \\
\hline & $(1.40)$ & $(1.40)$ \\
\hline \multirow[t]{2}{*}{$\mathrm{ROAA}$} & -2.590 & $-2.590^{\prime}$ \\
\hline & $(-3.68)$ & $(-3.68)$ \\
\hline \multirow[t]{2}{*}{ ROAE } & $0.0740^{*}$ & $0.0740^{*}$ \\
\hline & $(2.7 /)$ & $(2.77)$ \\
\hline \multirow[t]{2}{*}{ Total Assets (log) } & -0.539 & -0.539 \\
\hline & $(-0.93)$ & $(-0.93)$ \\
\hline \multirow[t]{2}{*}{2006} & 0 & 0 \\
\hline & (.) & (.) \\
\hline \multirow[t]{2}{*}{2007} & 1.498 & $1.638^{*}$ \\
\hline & $(1.80)$ & (197) \\
\hline \multirow[t]{2}{*}{2008} & 5.716 & 5.676 \\
\hline & (3.14) & (311) \\
\hline \multirow[t]{2}{*}{2009} & 4.964 & 4.684 \\
\hline & $(1.37)$ & $(129)$ \\
\hline \multirow[t]{2}{*}{2010} & 5.149 & 5.569 \\
\hline & $(1.40)$ & (152) \\
\hline \multirow[t]{2}{*}{2011} & 4.560 & $7.140^{*}$ \\
\hline & $(1.29)$ & $(2.01)$ \\
\hline \multirow[t]{2}{*}{2012} & 7.684 & 7.794 \\
\hline & (1.31) & (1.33) \\
\hline \multirow[t]{2}{*}{2013} & 2.826 & 2.506 \\
\hline & $(0.56)$ & $(0.50)$ \\
\hline \multirow[t]{2}{*}{2014} & 4.483 & 1953 \\
\hline & $(0.85)$ & $(0.37)$ \\
\hline \multirow[t]{2}{*}{2015} & 6.094 & 3.274 \\
\hline & (1.14) & $(0.61)$ \\
\hline $\mathbf{N}$ & 273 & 273 \\
\hline within & 0,0998 & 0,0986 \\
\hline between & 0,1675 & 0,1672 \\
\hline \multirow[t]{2}{*}{ overall } & 0,1268 & 0,1257 \\
\hline & 298 & \\
\hline
\end{tabular}


Regression table on investors' decisions on buying banks subordinated bonds. Regressions are run with the fixed effect estimation method and robust error to avoid heteroskedasticity; t-statistic in parenthesis. $*, * *$ and $* * *$ denote statistical significance at the $5 \%, 1 \%$ and $0,1 \%$ levels, respectively.

The investors decision are analyzed through equations (5) and (6):

(5) Yield $=\mathrm{a}_{0}+\mathrm{a}_{1} \boldsymbol{\Sigma} \mathrm{V}^{\text {Bank }_{\mathrm{i}, \mathrm{t}}}+\mathrm{a}_{2} \boldsymbol{\Sigma} \mathrm{V}^{\text {Bond }} \mathrm{i,t}+\mathrm{a}_{3}$ Rating $_{\mathrm{i}, \mathrm{t}}+\mathrm{a}_{4} \boldsymbol{\Sigma} \mathrm{D}^{\mathrm{time}}+\varepsilon_{\mathrm{i}, \mathrm{t}}$;

(6) BondSpread $=\mathrm{a}_{0}+\mathrm{a}_{1} \boldsymbol{\Sigma} \mathrm{V}_{\mathrm{Bank}_{\mathrm{i}, \mathrm{t}}}+\mathrm{a}_{2} \boldsymbol{\Sigma} \mathrm{V}_{\mathrm{Bond}_{\mathrm{i}, \mathrm{t}}}+\mathrm{a}_{3} \boldsymbol{\Sigma} \mathrm{V}^{\text {Regulation }}{ }_{\mathrm{i}, \mathrm{t}}+\mathrm{a}_{4} \boldsymbol{\Sigma} \mathrm{D}^{\text {time }}+\varepsilon_{\mathrm{i}, \mathrm{t}}$;

where, where $V^{\text {Bank }}$ are the variables characterizing the issuing bank (Return on Average Assets; Return on Average Equity; Total Assets); $\mathrm{V}^{\mathrm{B} o n d}$ are the variables characterizing the individual bond issued (Volume; Rating) and $\mathrm{D}^{\text {time }}$ is a dummy variable for the time series. 